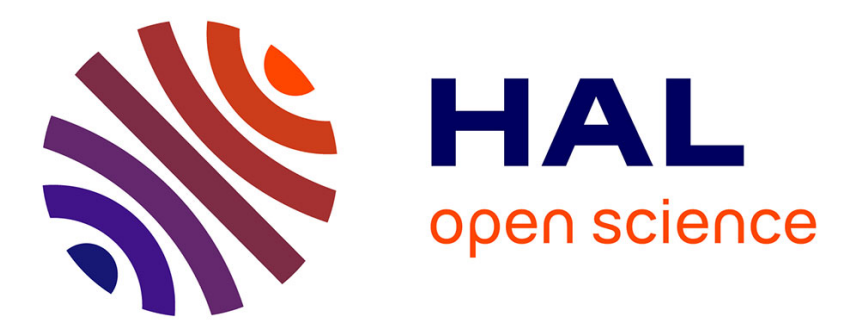

\title{
Inverted responses of the carbon cycle to orbital forcing in Mesozoic peri-platform marginal basins: implications for astrochronology
}

Mathieu Martinez, Landry Guillois, Philippe Boulvais, Jean-françois Deconinck

\section{To cite this version:}

Mathieu Martinez, Landry Guillois, Philippe Boulvais, Jean-françois Deconinck. Inverted responses of the carbon cycle to orbital forcing in Mesozoic peri-platform marginal basins: implications for astrochronology. Paleoceanography and Paleoclimatology, 2020, 35 (6), pp.e2019PA003705. 10.1029/2019PA003705 . insu-02611080

\section{HAL Id: insu-02611080 \\ https://hal-insu.archives-ouvertes.fr/insu-02611080}

Submitted on 30 Jun 2020

HAL is a multi-disciplinary open access archive for the deposit and dissemination of scientific research documents, whether they are published or not. The documents may come from teaching and research institutions in France or abroad, or from public or private research centers.
L'archive ouverte pluridisciplinaire HAL, est destinée au dépôt et à la diffusion de documents scientifiques de niveau recherche, publiés ou non, émanant des établissements d'enseignement et de recherche français ou étrangers, des laboratoires publics ou privés. 


\section{Paleoceanography and Paleoclimatology}

\author{
RESEARCH ARTICLE \\ 10.1029/2019PA003705 \\ Key Points: \\ - The $\delta^{13} \mathrm{C}_{\text {carb }}$ measured in \\ hemipelagic marl and limestone \\ beds shows opposite responses to \\ eccentricity depending on the source \\ of carbonates \\ - A careful control of the source of \\ carbonates should be done before \\ using $\delta^{13} \mathrm{C}_{\text {carb }}$ series for \\ astronochronology in Mesozoic \\ marginal basins \\ - Comparisons with the insolation \\ models suggest that more \\ carbonated intervals occurred at \\ eccentricity maxima
}

Correspondence to:

M. Martinez,

mathieu.martinez@univ-rennes1.fr

\section{Citation:}

Martinez, M., Guillois, L., Boulvais, P., \& Deconinck, J.-F. (2020). Inverted responses of the carbon cycle to orbital forcing in Mesozoic periplatform marginal basins: Implications for astrochronology. Paleoceanography and Paleoclimatology, 35, e2019PA003705. https://doi.org/10.1029/2019PA003705

\section{Received 30 JUN 2019}

Accepted 24 APR 2020

Accepted article online 8 MAY 2020

(C)2020. American Geophysical Union. All Rights Reserved.

\section{Inverted Responses of the Carbon Cycle to Orbital Forcing in Mesozoic Periplatform Marginal Basins: Implications for Astrochronology}

\author{
Mathieu Martinez ${ }^{1}$ (D), Landry Guillois ${ }^{1}$, Philippe Boulvais ${ }^{1}$, and Jean-François Deconinck ${ }^{2}$ \\ ${ }^{1}$ Univ Rennes, CNRS, Géosciences Rennes-UMR 6118, Rennes, France, ${ }^{2}$ Université de Bourgogne-Franche-Comté, \\ UMR CNRS/UBFC 6282 Biogéosciences, Dijon, France
}

\begin{abstract}
Astrochronology depends on the faithful record of insolation forcing in climatic proxies, including the carbon isotope composition measured on bulk carbonates $\left(\delta^{13} \mathrm{C}_{\mathrm{carb}}\right)$. In marginal basins close to carbonate platforms, the source of carbonate is varied, which can impact the record of the astronomical cycles in the $\delta^{13} \mathrm{C}_{\text {carb }}$ signal. We compare here the $\delta^{13} \mathrm{C}_{\text {carb }}$ values together with detrital and weathering proxies before and during a crisis in the platform carbonate production (Weissert event, Valanginian, $\sim 135 \mathrm{Ma}$ ) to document how a change in the carbonate source can affect the record of the orbital forcing by the carbon isotope system. The level of burial diagenesis was insufficient to alter the clay mineral assemblages, which are linked to cyclic changes in weathering conditions. The $\delta^{13} \mathrm{C}_{\text {carb }}$ values correspond to the values measured in other parts of the basin, which experienced various levels of burial diagenesis, suggesting that they also reflect a paleoenvironmental signal. In marl beds, the $\delta^{13} \mathrm{C}_{\text {carb }}$ values increase with detrital and kaolinite content, suggesting that humid/arid cycles controlled the evolution of the $\delta^{13} \mathrm{C}_{\text {carb }}$ signal in marl beds. Before the Weissert event, the $\delta^{13} \mathrm{C}_{\text {carb }}$ values in the limestone beds increase with $\mathrm{CaCO}_{3}$ content and arid conditions. This can reflect the change of type of carbonate produced in shallow-marine environments and exported to the basin. These environmental changes disrupted the record of the eccentricity cycles in the $\delta^{13} \mathrm{C}_{\text {carb }}$ signal. The sources of carbonate must therefore be clearly identified and documented before using the $\delta^{13} \mathrm{C}_{\text {carb }}$ series for orbital tuning in hemipelagic areas close to carbonate platforms.
\end{abstract}

Plain Language Summary The Milankovitch cycles are periodic motions of the Earth's orbit at the origin of cyclic climatic changes recorded in strata. Regular decimetric alternations between marl and limestone strata deposited in deep seas are notably caused by humid-arid cycles orbitally induced, which usually take $\sim 20,000 \mathrm{yr}$ to be deposited. Counting these strata cycles allows the duration of the geological periods to be calculated. The so-called astronomical timescales depend on the faithful stratal record of the Milankovitch cycles. Carbon isotopes are used to build astronomical timescales despite sources of carbon are varied and often unconstrained. We compare here proxies from the continental weathering and erosion to the marine carbonate production recorded in marl-limestone alternations. We show here that the different sources of carbonates - produced by organisms with variated ecological needs—disrupt the record of the Milankovitch cycles in the carbon isotopes. The sources of carbon in sediments have to be compared to additional climatic proxies before being used for astronomical timescales. In addition, we propose models to explain how the Milankovitch cycles can be recorded and disrupted in the proxies studied here.

\section{Introduction}

The construction of the geological timescale depends on the reliable identification of the orbital forcing on sedimentary series (Hinnov \& Hilgen, 2012). The insolation cycles can be recorded in the sedimentary columns through periodic modifications of the atmospheric and oceanic circulations, controlling in turn temperatures, precipitation, vegetation cover, erosion level, ice volume, atmospheric composition, primary productivity, or oceanic redox conditions (Strasser et al., 2006). Periodic modifications of the detrital supply to the basins and of the carbonate production are notably at the origin of the orbitally induced hemipelagic marl-limestone alternations, which constitute spectacular testimonies of the Milankovitch forcing on sediment (Cotillon, 1987; Einsele \& Ricken, 1991; Gilbert, 1895; Martinez, 2018; Mutterlose \& Ruffell, 1999). The orbitally forced lithological cycles can be so subtle that visual inspection does not 

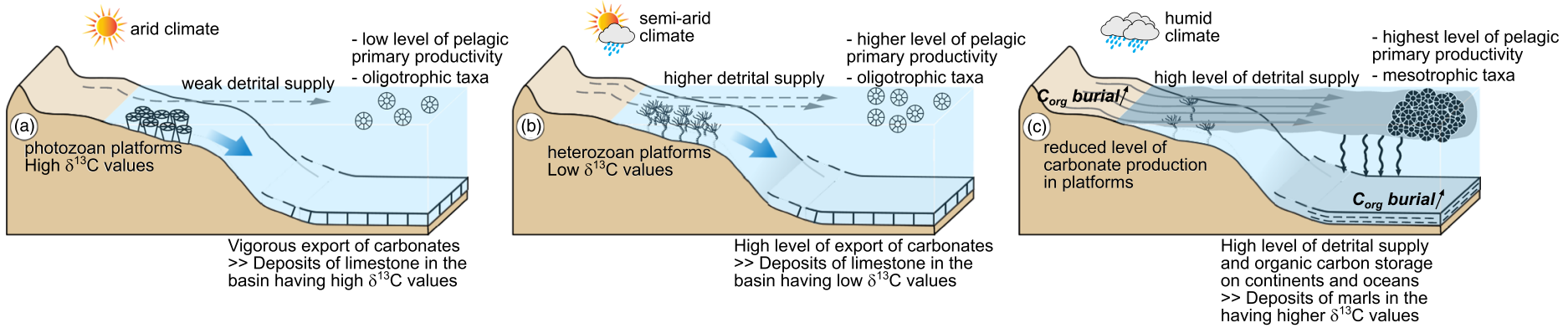

\begin{tabular}{lc}
+ smectite & Clay mineralogy of the hemipelagic deposits \\
\hline+ & $\mathrm{CaCO}_{3}$ content of (hemi-) pelagic sediment \\
\hline- & TOC content of (hemi-) pelagic sediment
\end{tabular}
having higher $\delta^{13} \mathrm{C}$ values

$\underset{+}{\rightarrow}$

Figure 1. (a-c) Model of the link between climate, detrital supply, type of carbonate producers, pelagic productivity, pelagic sedimentary deposit, $\delta^{13} \mathrm{C}_{\mathrm{carb}}$ of the deposits in the Vocontian Basin, clay mineral assemblages, $\mathrm{CaCO}_{3}$ contents of (hemi)pelagic sediment, and level of organic carbon burial. The model is modified from Föllmi et al. (2006).

allow their objective recognition. Thus, the measurements of paleoclimatic proxies at high resolution together with spectral analyses are required to identify sedimentary cycles linked to orbital forcing (e.g., Ghirardi et al., 2014; Matys Grygar et al., 2017). Then, filtering is usually done on a target cycle, whose duration is known, to count the number of cycles and calculate durations (e.g., Zeeden et al., 2018). A large variety of proxies have been applied to detect the sedimentary record of the orbital cycles. These include (i) lithologic proxies: magnetic susceptibility (MS), gamma ray spectrometry, color levels, or bed thickness (see, for instance, Li et al., 2019); (ii) geochemical proxies: oxygen and carbon isotope ratios (Pälike et al., 2006), element contents and ratios (Vahlenkamp et al., 2020), and total organic carbon (Huang et al., 2010); (iii) mineralogical proxies: clay mineral assemblages (Moiroud et al., 2012) and wt\% $\mathrm{CaCO}_{3}$ (Herbert et al., 1986); and (iv) paleontological proxies: relative abundance, diversity, or size of planktic or benthic taxa (Hays et al., 1976; Suchéras-Marx et al., 2010) and type and abundance of ichnofossils (Rodríguez-Tovar et al., 2011).

The trends in the carbon isotope ratios have previously been interpreted as a proxy for $\mathrm{C}_{\text {org }}$ versus $\mathrm{C}_{\text {carb }}$ production as a response of changes in detrital supply and sea level (Jarvis et al., 2006; Martinez \& Dera, 2015; Weissert et al., 1998). As these changes are related to orbital forcing, the $\delta^{13} \mathrm{C}$ signal is a convenient proxy to establish astronomical timescales (Pälike et al., 2006; Zachos et al., 2001). However, the comparison of $\delta^{13} \mathrm{C}$ curves with lithological proxies shows changes in the correlation between the carbon cycle and the lithology (see Ait-Itto et al., 2018; Bajnai et al., 2017; Giorgioni et al., 2012; Grippo et al., 2004). These changes in correlations notably modify the number of repetitions of the target frequency from one proxy to another and increase the uncertainty in the calculation of the duration of the geological period of interest. In a given sedimentary basin, the change in environmental conditions can change the source of carbon at a basin scale and locally modify the response of the carbon cycle to the orbital forcing. For instance, in (hemi)pelagic marl-limestone alternations deposited in marginal basins near carbonate platforms, limestone beds commonly originate from the export of carbonate produced in shallow-marine environments (Colombié \& Strasser, 2003; Pittet \& Mattioli, 2002) until the mid-Cretaceous. In the Late Cretaceous and the Cenozoic, the limestone beds may be formed by the export from shallow-marine environments and/or pelagic production (Beltran et al., 2009; Van Os et al., 1994). In the Vocontian Basin (Southeastern France), quantification of the pelagic and nonpelagic carbonates has been made before the mid-Cretaceous (Gréselle et al., 2011) and shows that the platform-derived carbonates were the main constituent of the carbonates. The flux of pelagic producers was the highest when the $\mathrm{wt} \% \mathrm{CaCO}_{3}$ content of the sediment reaches the lowest values during the Weissert event, an episode of environmental changes marked by enhanced continental weathering and trophic levels, which led to a crisis in the production of shallow-marine carbonates (DuchampAlphonse et al., 2014; Erba et al., 2004; Mattioli et al., 2014). Knowing the balance between pelagic and platform-derived carbonate, changing the type of shallow-marine or pelagic carbonate producers necessarily impacts the value of $\delta^{13} \mathrm{C}$ of the carbonates deposited in the basin (Figure 1). The climate conditions can 


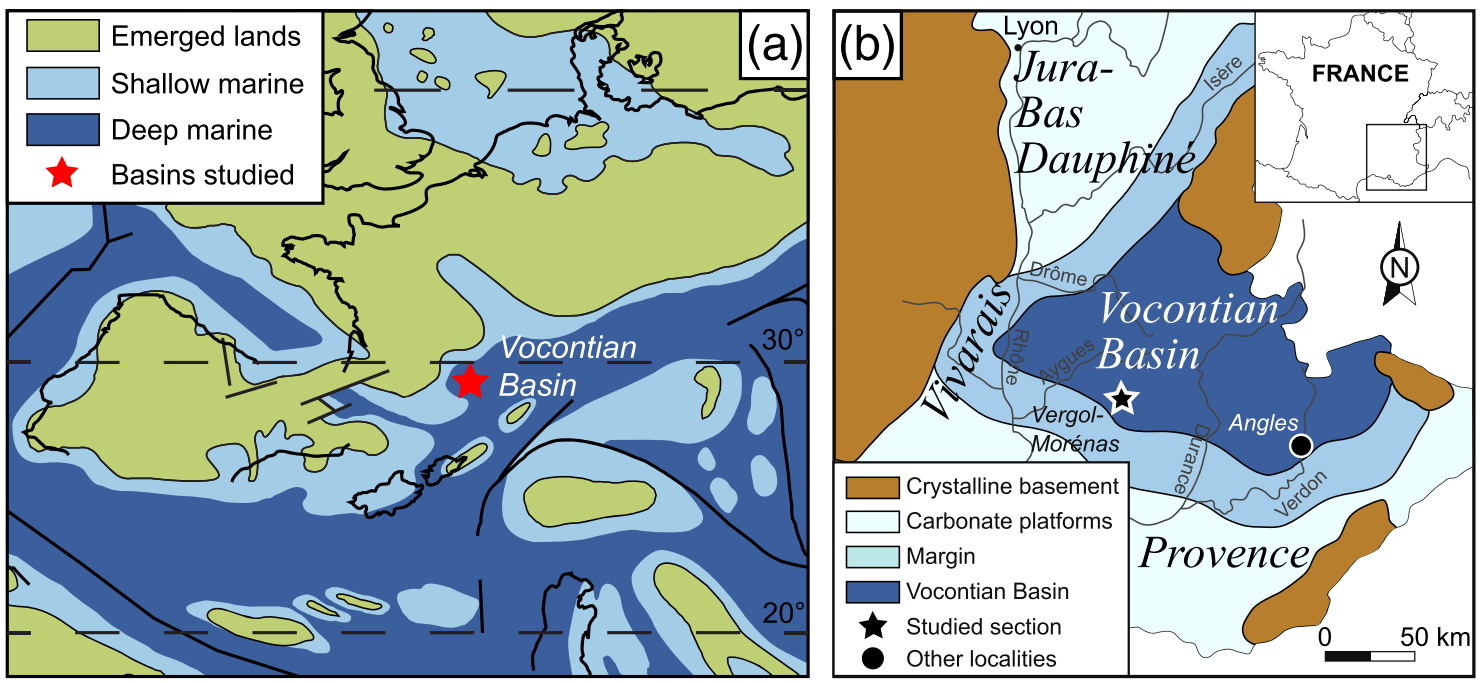

Figure 2. (a) Paleogeographic map of the Western Tethys during the Early Cretaceous (from Dercourt et al., 1993) with location of the Vocontian Basin. (b) Location of the section studied in the Vocontian Basin (from Gréselle \& Pittet, 2010).

modify the source of carbonate in the (hemi)pelagic marl-limestone alternations. Such a modification can inverse the response of the carbon cycle to the orbital forcing and prevent the use of the $\delta^{13} \mathrm{C}$ signal for astrochronology. The $\delta^{13} \mathrm{C}$ values measured on bulk carbonate in hemipelagic marl-limestone alternations are here compared to clay mineral assemblages and MS before and during a crisis of the shallow-marine carbonate producers. We aim here to test the impact of the change in carbonate sources on the response of the carbon cycle to orbital forcing in deep-marine marginal basins located near carbonate platforms.

\section{Geological Setting}

During the Early Cretaceous, the Vocontian Basin, part of the Dauphino-Helvetic Zone of the external western Alps of France, was located at a paleolatitude of about $30^{\circ}$ on the northern margin of the Tethys Ocean (Dercourt et al., 1993; Figure 2a). It was surrounded by the Vivarais Margin to the west and by the carbonate platforms of the Jura-Bas Dauphiné to the north and of Provence to the south (Figure 2b). The Vocontian Basin was open only to the east to the Tethys Ocean (Figure 2a). The thick lower Cretaceous deposits consist of decimetric marl-limestone alternations occasionally interrupted by gravity flow deposits (e.g., slumping) deposited in a (hemi)pelagic environment, that is, below the storm wave limit. The macrofauna is dominantly composed of ammonites and belemnites and also contains a small amount of bivalves and gastropods (Reboulet et al., 2003). The microfossils include calcareous nannofossils, foraminifers, ostracods, and dynocysts (Blanc, 1996). They point to a water depth estimated at several hundred of meters (Wilpshaar \& Leereveld, 1994).

In the western part of the Vocontian Basin-where the influence of thermal diagenesis is low-kaolinite and illite clay minerals are more abundant in the marl beds, whereas smectite is more abundant in the limestone beds (Deconinck \& Chamley, 1983; Deconinck, 1987; Levert \& Ferry, 1988; Figure 1). The lithological alternations reflect humid/arid cycles in which marls were deposited under tropical humid climate, marked by high levels of continental weathering and high levels of detrital and nutrient exports to the basin (Deconinck \& Chamley, 1983; Mutterlose \& Ruffell, 1999; Figure 1). Limestone beds were deposited in a more arid climate, marked by low levels of detrital and nutrient exports to the basin. Spectral analyses and visual inspection both highlighted that these alternations can be grouped into bundles of 5 to 20 alternations, which mark the imprint of the short and long eccentricity and the precession cycles (Gréselle \& Pittet, 2010; Martinez et al., 2015). The calcareous nannofossil flux and the abundance of bivalves and gastropods are higher in marl beds than in limestone beds (Giraud et al., 2013; Gréselle et al., 2011; Reboulet et al., 2003), whereas the ecological communities are dominated by mesotrophic assemblages (Figure 1). These are likely to be a consequence of increased trophic levels during humid climate and subsequent increased detrital and nutrient input (Giraud et al., 2013). Conversely, ecological communities in 


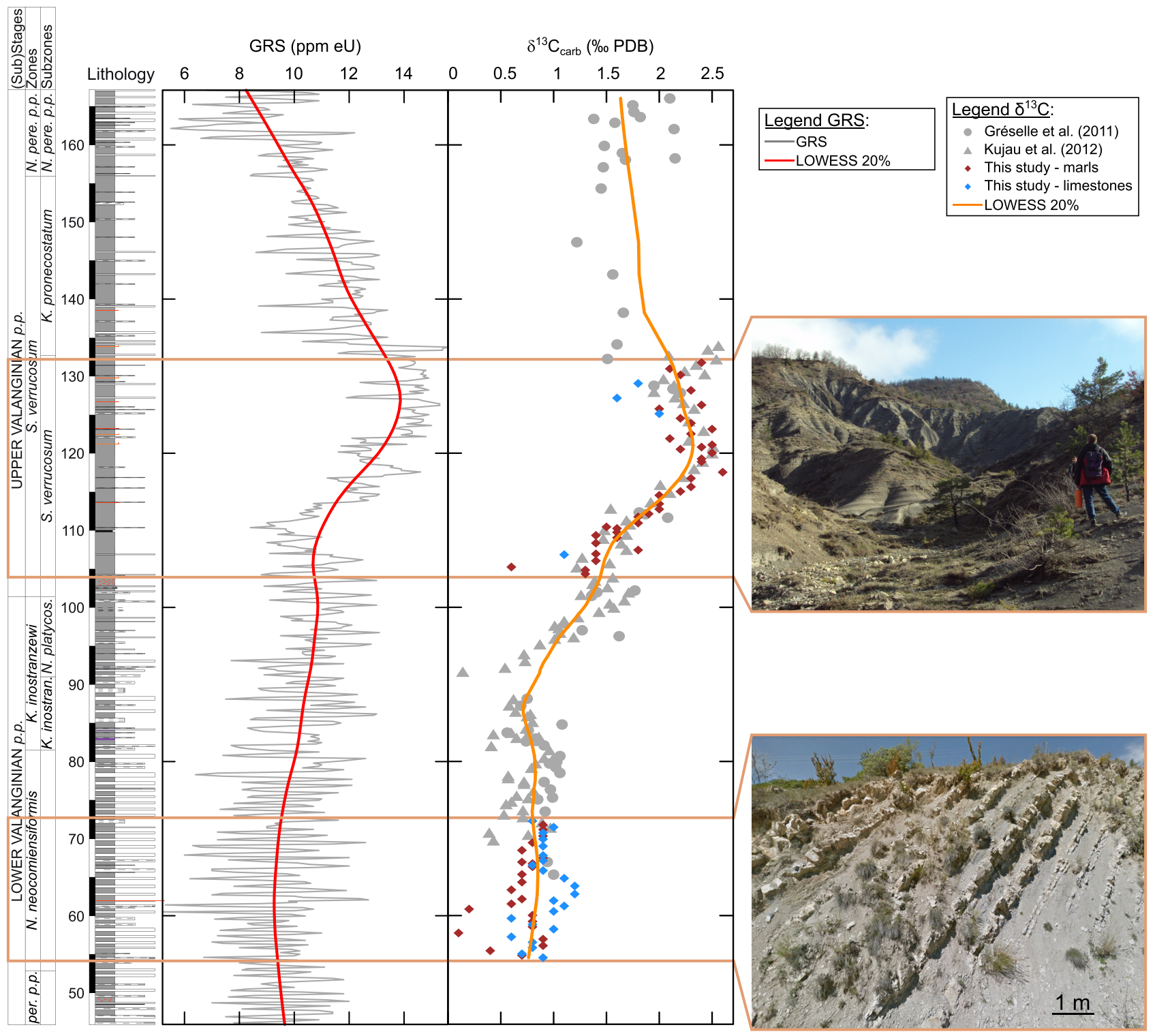

Figure 3. Vergol-Morénas composite section showing the log of the section, the gamma ray spectrometry (GRS) available in Martinez et al. (2013), the $\delta^{13} \mathrm{C}$ curves from Gréselle et al. (2011), Kujau et al. (2012), and this study (blue and brown diamonds), and the pictures of the two sequences of the Vergol-Morénas section studied here. LOWESS = LOcally WEighted Scatterplot Smoothing (Cleveland, 1979).

limestone beds indicate reduced fluxes of calcareous nannofossils dominated by oligotrophic taxa, reflecting decreased trophic levels of the basin under more arid climate conditions. Correlations from distal to proximal marine environments and of the fossil content in the limestone beds indicate that these hemipelagic limestone beds originate from the exports of carbonate from shallow-marine environments (Reboulet et al., 2003). The link between marl-limestone alternations and sea-level changes can depend on the morphology of these proximal marine environments (homoclinal ramp, rimmed, or open platform; Pittet \& Strasser, 1998). Conversely, the marl-limestone alternations of the Vocontian Basin are always linked to cycles in the clay mineral assemblages and are thus indicative of humid-arid cycles.

The Vergol section, studied here, is located in the southern part of the Vocontian Basin (Figure 2b), in the Drôme Department between Aulan, to the north, and Montbrun-les-Bains, to the south. The section starts in the uppermost Berriasian and records the Berriasian-Valanginian boundary (Blanc, 1996; Figure 3). The detailed ammonite and calcareous nannofossil biostratigraphic schemes provided in this section make it one of the two candidates for the Valanginian Global Stratotype Sections and Points (GSSPs; Reboulet \& 
Atrops, 1999; Gradstein et al., 2012; Kenjo et al., 2014). The section crops out up to the upper Valanginian. At the transition between the lower and the upper Valanginian strata, the quality of the outcrop is much better in the nearby section of Morénas, next to Aulan, $4 \mathrm{~km}$ north of Vergol. Marker beds make the two sections easily correlatable (McArthur et al., 2007; Reboulet, 1996; Reboulet et al., 2003). As the bed pattern is identical in both sections, they are usually regarded as one composite series (Kujau et al., 2012; Martinez et al., 2013). The marl-limestone alternations are carbonate dominated in the Berriasian ( $80 \mathrm{wt} \% \mathrm{CaCO}_{3}$ on average; Giraud et al., 1995) and progressively enriched in clay throughout the uppermost Berriasian to the base of the upper Valanginian (Figure 3). In the lower Valanginian, the alternations have a mean wt $\% \mathrm{CaCO}_{3}$ content around 65\% (Giraud et al., 1995) and are composed of marl and limestone beds of equal thicknesses. At the base of the upper Valanginian, the alternations vanish in favor of a 30-m-thick claystone formation in which thin and scarce limestone beds intercalate (Figure 3), with mean wt $\mathrm{CaCO}_{3}$ content lower than 50\% (Giraud et al., 1995). The scarcity of limestone beds in this interval is interpreted to be a consequence of the crisis in neritic carbonate producers that led to decreased exports of carbonate to the basin (Föllmi et al., 2006). The astrochronology of the Vergol section was established on the basis of the 405-kyr eccentricity cycle filtered from spectral gamma ray data measured in the Vergol-Morénas and other sections in the Vocontian Basin (Martinez et al., 2013). Two sequences of 405-kyr duration each are studied here. Sequence 1 (hereafter S1) is in the lower Valanginian, at the transition between the Tirnovella pertransiens and the Busnardoites campylotoxus ammonite zones (Reboulet et al., 2011) or within the Neocomites neocomensiformis Zone according to recent revision of the biostratigraphic scheme (Reboulet et al., 2014). Mixed carbonate-detrital alternations crop out in S1 (Figure 3). Sequence 2 (hereafter S2) is at the base of the upper Valanginian, within the Saynoceras verrucosum Zone (Reboulet et al., 2011), where thick marl deposits are observed (Figure 3).

\section{Material and Methods}

\subsection{Sampling}

A total of 46 samples for S1 and 43 for S2 was collected, which represents a sample per ca. 10-kyr duration each, either two samples per lithological cycle (or precession cycles). In S1, samples were taken in the middle of each limestone and marl beds. In S2, gamma ray measured in Martinez et al. (2013) guided the choice of samples, as gamma ray is related to lithology. Samples were each taken at local maxima and minima of the gamma ray curve, which correspond respectively to local maxima and minima in clay content. In laboratory, samples were washed, and the weathered part of the carbonate samples was removed with a saw. The MS, stable isotopes, and clay mineral assemblages were then measured for each sample.

For the stable isotope and clay mineralogy analyses, the softer and most friable samples were finely powdered in an Abich mortar (steel) and then in a boron carbide mortar. The hardest samples were powdered in an agate mortar.

\subsection{MS and Calcimetry}

The MS was measured using a Kappabridge KLY-3S at Geosciences Laboratory, University of Rennes 1. Samples were crushed or sawed depending on their lithology into pieces of $\sim 10-20 \mathrm{~g}$ and set into a plastic container. The samples were then weighed, and their volumic MS was measured three times and corrected from blank measurements. The massic MS was then calculated by normalizing the volumic MS to the sample mass. The results are expressed in $\mathrm{m}^{3} \mathrm{~kg}^{-1}$ and given with a precision of $\pm 4 \times 10^{-10} \mathrm{~m}^{3} \mathrm{~kg}^{-1}$. The $\mathrm{CaCO}_{3}$ content was measured to verify that the MS fluctuations are linked to the lithology. The measurements were performed following the volumetric method employing a Bernard calcimeter. The uncertainty of the measurements is below 5\% (Lamas et al., 2005).

\subsection{Stable Isotopes $\left(\delta^{13} \mathrm{C}\right.$ and $\left.\delta^{18} \mathrm{O}\right)$}

The carbon and oxygen isotope compositions were analyzed at Geosciences Laboratory, University of Rennes 1 . The amount of powder required from each sample was calculated according to its $\mathrm{CaCO}_{3}$ estimated percentage. Powder is reacted with anhydrous phosphoric acid $\left(\mathrm{H}_{3} \mathrm{PO}_{4}\right)$ for a few hours at $50^{\circ} \mathrm{C}$. The produced $\mathrm{CO}_{2}$ was isolated in a vacuum line and then analyzed with a VG Optima triple-collector mass spectrometer. The $\delta^{13} \mathrm{C}$ values are expressed in Pee Dee Belemnite (PDB) and the $\delta^{18} \mathrm{O}$ values in Standard Mean Ocean Water (SMOW) and then converted in PDB. A lab internal standard (Prolabo Rennes) was 
measured continuously during the experiment and attest of the result accuracy. The Prolabo Rennes and replicate analyses of some samples allow estimating a global uncertainty $(1 \sigma)$ of $\pm 0.05 \%$ o for $\delta^{13} \mathrm{C}$ and $\pm 0.2 \%$ o for $\delta^{18} \mathrm{O}$.

\subsection{Clay Mineralogy}

Mineralogical analyses were performed at the Biogeosciences Laboratory, University of Bourgogne FrancheComté. Clay mineral assemblages were identified by X-ray diffraction (XRD) on oriented mounts of noncalcareous clay-sized particles $(<2 \mu \mathrm{m})$, following the analytical procedure of Moore and Reynolds (1997). After removing carbonate using $0.2-\mathrm{N} \mathrm{HCl}$, deflocculation of clays was completed by repeated washing with distilled water. Particles finer than $2 \mu \mathrm{m}$ were concentrated by centrifugation. Diffractograms were obtained using a Bruker D4 Endeavor diffractometer with $\mathrm{CuK}_{\alpha}$ radiation with LynxEye detector and Ni filter, under $40-\mathrm{kV}$ voltage and 25-mA intensity. Three preparations were analyzed, the first after air drying, the second after ethylene-glycol solvation, and the third after heating at $490^{\circ} \mathrm{C}$ for $2 \mathrm{hr}$. The goniometer was scanned from $2.5^{\circ}$ to $28.5^{\circ}$ for each run. Three XRD runs were obtained; the clay minerals were identified by the position of their main diffraction peak, and their proportions were estimated in relation to their area. Areas were determined on diffractograms of glycolated runs with MacDiff 4.2.5 software (Petschick, 2000). Replicate analyses of some samples and the internal procedure of quantification using MacDiff on mixtures of clay minerals in known proportions allow to estimate the uncertainty of the relative proportions of the clay minerals as $5 \%$.

\section{Results}

\section{1. $\mathrm{S} 1$}

The MS values in S1 range from $16.6 \times 10^{-9}$ to $29.1 \times 10^{-9} \mathrm{~m}^{3} \mathrm{~kg}^{-1}$ in the limestone beds, while they range from $27.5 \times 10^{-9}$ to $41.9 \times 10^{-9} \mathrm{~m}^{3} \mathrm{~kg}^{-1}$ in the marl beds (Figures 4 and 5). The average MS value is $21.6 \times 10^{-9} \mathrm{~m}^{3} \mathrm{~kg}^{-1}$ in limestone beds and $35.8 \times 10^{-9} \mathrm{~m}^{3} \mathrm{~kg}^{-1}$ in marl beds. The $\mathrm{CaCO}_{3}$ content ranges from $75 \%$ to $89 \%$ in limestone beds and from $41 \%$ to $50 \%$ in marl beds. The average wt $\% \mathrm{CaCO}_{3}$ content is $82 \%$ in limestone beds and $50 \%$ in marl beds.

The $\delta^{18} \mathrm{O}_{\text {carb }}$ values range from $-1.3 \%$ to $-0.8 \%$ PDB in limestone beds and from $-2.2 \%$ o to $-1.1 \%$ PDB in marl beds (Figures 4 and 5). The average $\delta^{18} \mathrm{O}_{\text {carb }}$ value is $-1.1 \%$ PDB in limestone beds and $-1.5 \%$ PDB in marl beds. The $\delta^{13} \mathrm{C}_{\text {carb }}$ values range from $0.6 \%$ to $1.2 \%$ PDB in limestone beds and from $0.1 \%$ to $0.9 \%$ PDB

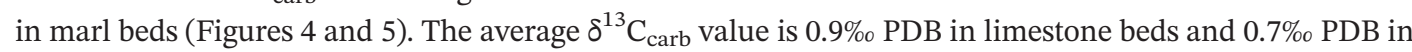
marl beds. These values are generally in agreement with values previously published by Gréselle et al. (2011) and Kujau et al. (2012) (Figure 3). Three values are nonetheless outstandingly low compared to their neighboring data (Figure 4).

The clay mineral assemblages are composed of kaolinite, illite, R0-type illite-smectite mixed layers (I-S R0 hereafter called smectite), chlorite, illite, and R1-type illite-smectite mixed layers (I-S R1). In the clay fraction of limestone beds, kaolinite and illite contents range from $2 \%$ to $18 \%$ and from $13 \%$ to $21 \%$, respectively. The proportions of these minerals are higher in the clay fraction of marl beds, $7 \%$ to $27 \%$ of kaolinite and $13 \%$ to $28 \%$ of illite (Figures 4 and 5). Smectite and chlorite contents respectively range from $29 \%$ to $51 \%$ and from $14 \%$ to $48 \%$ of the clay fraction of limestone beds. The proportions of these minerals are lower in the clay fraction of marl beds, ranging from $24 \%$ to $44 \%$ of smectite and from $7 \%$ to $27 \%$ of chlorite (Figures 4 and 5). The proportion of the I-S R1 in the clay mineral assemblages ranges from traces to $16 \%$ in limestone beds (average: $8 \%$ ), while it ranges from 3\% to 15\% in marl beds (average: 9\%) (Figures 4 and 5).

Compared to their adjacent limestone beds, marl beds show higher MS values, lower $\delta^{18} \mathrm{O}$ values, higher contents in kaolinite and illite, and lower contents in chlorite and smectite (Figures 4 and 5). At high frequency, the MS values correlate with kaolinite and illite content and inversely correlate with $\delta^{18} \mathrm{O}_{\text {carb }}$ values and smectite content. The variations in the content in I-S R1 do not systematically follow the change in lithology. The $\delta^{13} \mathrm{C}_{\text {carb }}$ values show various behaviors within S1. In the lower and upper parts of S1 (respectively intervals S1a and S1c), the $\delta^{13} \mathrm{C}_{\text {carb }}$ values are not significantly different between marl and adjacent limestone and do not show high-frequency cycles consistent with lithology. In the middle part of S1 (Interval $\mathrm{S} 1 \mathrm{~b}$ ), the $\delta^{13} \mathrm{C}_{\text {carb }}$ series shows high-amplitude cycles linked to the lithology, with higher values in limestone beds than in marl beds. 

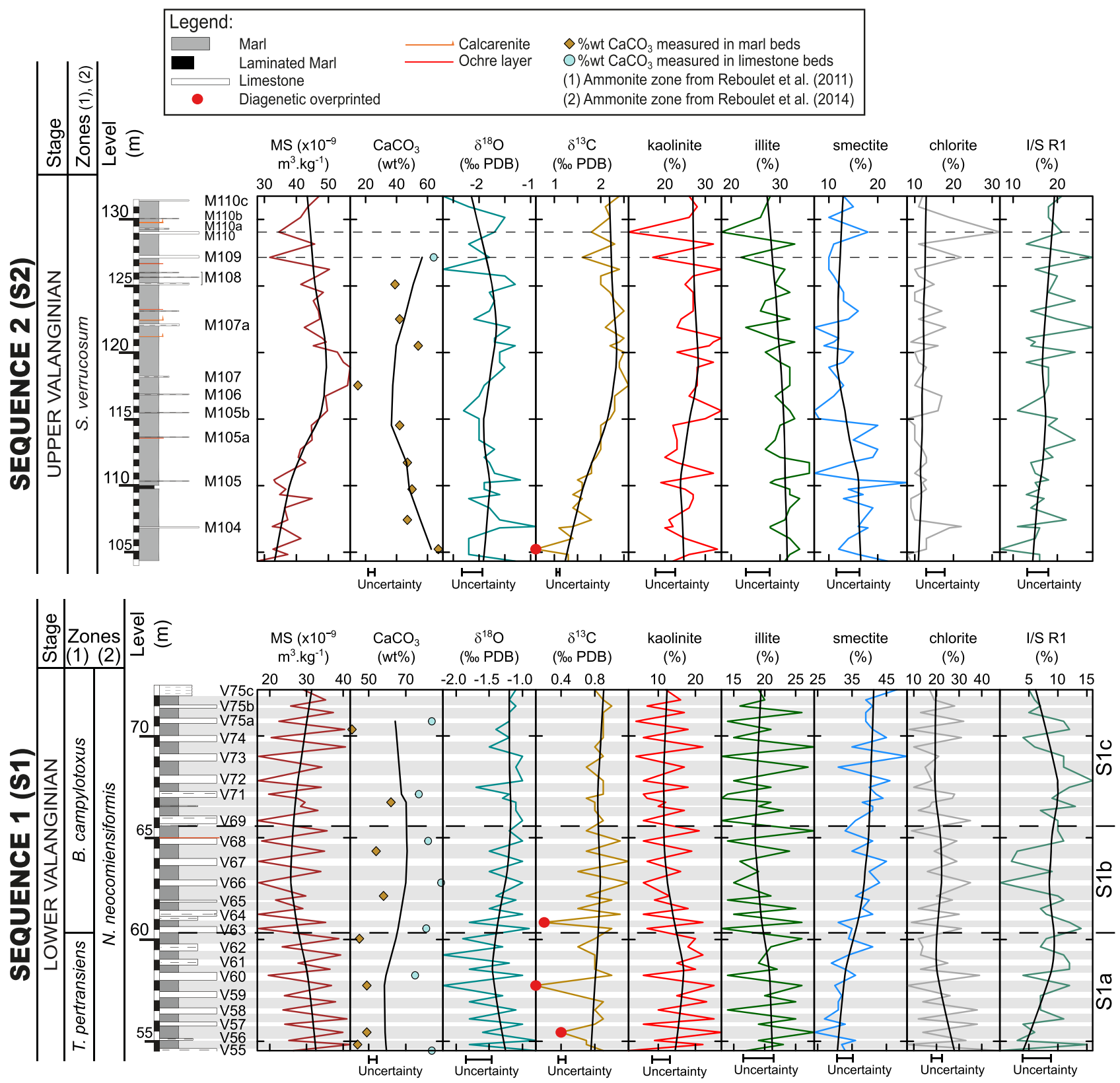

Figure 4. Magnetic susceptibility (MS), oxygen and carbon isotope ratios, and clay mineral assemblages of Sequences 1 and 2 (S1 and S2, respectively). Shaded gray lines in S1 are the projections of the marl beds. Black dashed lines are the projection of the prominent limestone beds.

The trend of the MS signal in S1 (thick black curve in Figure 4) broadly correlates with the trends of the kaolinite and illite signals and shows an inverse correlation with the trends of the $\delta^{18} \mathrm{O}_{\text {carb }}$ signal and smectite signals. The trend of the $\delta^{13} \mathrm{C}_{\text {carb }}$ signal displays no correlation with the other signals.

\section{2. $\mathrm{S} 2$}

The MS values in S2 range from $27.8 \times 10^{-9}$ to $56.8 \times 10^{-9} \mathrm{~m}^{3} \mathrm{~kg}^{-1}$ (Figures 4 and 5), with an average value of $42.7 \times 10^{-9} \mathrm{~m}^{3} \mathrm{~kg}^{-1}$. The wt $\% \mathrm{CaCO}_{3}$ content ranges from $15 \%$ to $67 \%$, with an average value of $47 \%$ (Figure 4). The $\delta^{18} \mathrm{O}_{\text {carb }}$ and $\delta^{13} \mathrm{C}_{\text {carb }}$ values respectively range from $-2.7 \%$ o to $-0.9 \%$ PDB (average: $-1.8 \%$ PDB) and from $0.6 \%$ to $2.6 \%$ PDB (average: $1.9 \%$ PDB). The clay fraction contains the same clay minerals as in S1 (Figures 4 and 5). Kaolinite content ranges from 11\% to 34\% (average: 26\%), illite from 

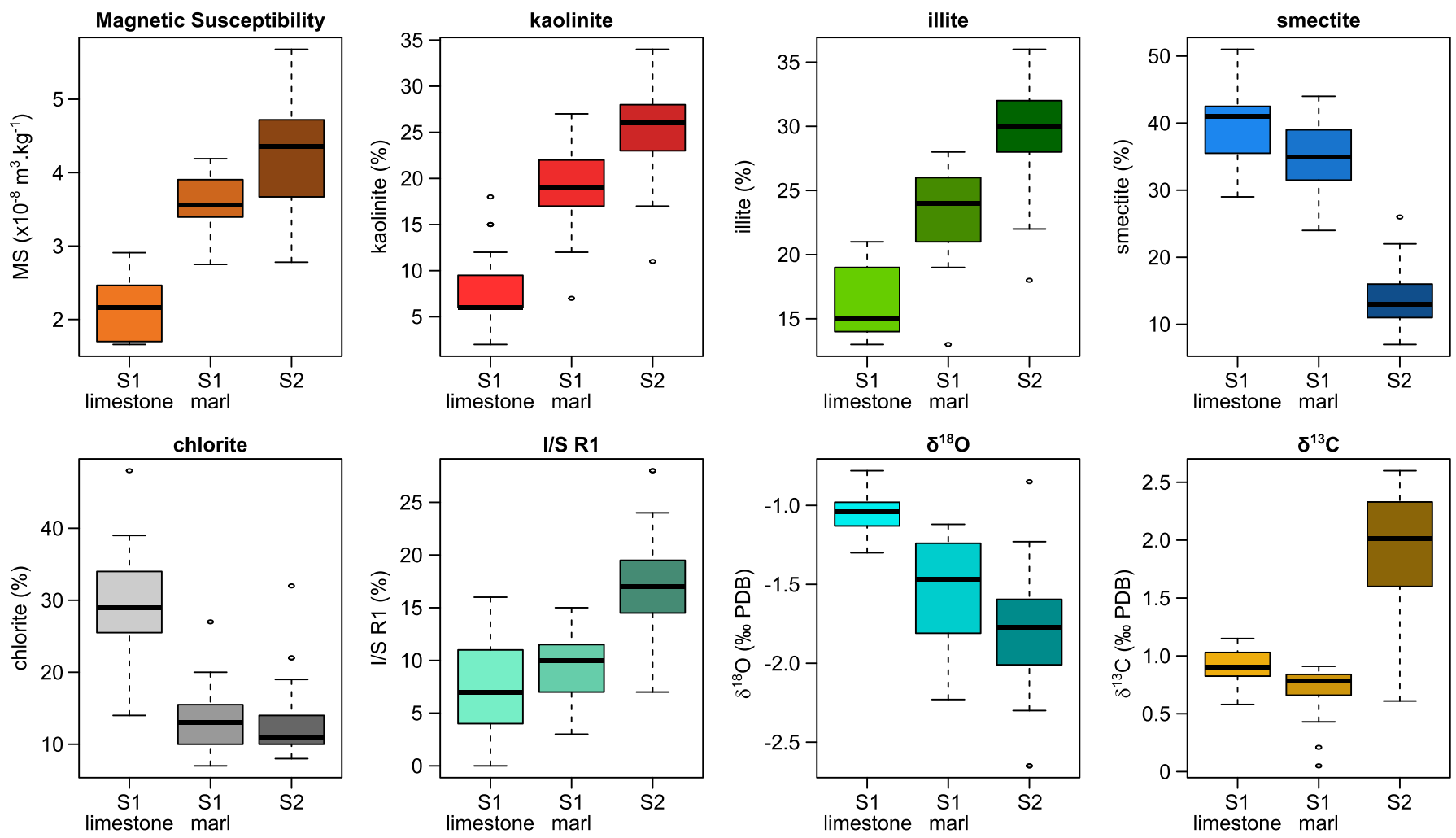

Figure 5. Boxplots of the magnetic susceptibility, clay minerals, and oxygen and carbon isotopes in limestone beds of S1 and marl beds of S1 and in S2. As the lithologic contrast vanishes in S2, we decided to gather all values of a considered proxy in S2 in one boxplot.

$18 \%$ to $36 \%$ (average: $30 \%$ ), smectite from $7 \%$ to $26 \%$ (average: $14 \%$ ), chlorite from $8 \%$ to $32 \%$ (average: $13 \%$ ), and I-S R1 from $7 \%$ to $28 \%$ (average: $17 \%$ ).

Throughout S2, the trends of kaolinite, MS, and $\delta^{13} \mathrm{C}$ series correlate, while they show an inverse correlation with smectite. A total of 39 out of the $43 \delta^{13} \mathrm{C}$ values measured here is within the range of values previously published in this interval (Figure 3). The four other values are lower than previously published. Three of these four samples are within prominent limestone beds in this interval (Figure 4).

\section{Discussion}

\subsection{Relation Between Lithology and Weathering Levels}

In both S1 and S2, kaolinite and illite contents increase with the MS value, while smectite content decreases (Figures 4 and 5). The MS signal shows a strong inverse correlation with the $\mathrm{CaCO}_{3}$ content, which indicates that higher MS values reflect the detrital content (Figure 6c). Kaolinite and illite contents thus increase with the level of detrital content in the marl-limestone alternations, while smectite content decreases.

In the Vergol-Morénas section, the organic matter is immature, with $T_{\max }$ values in mid-Valanginian organic-rich samples ranging from $427^{\circ} \mathrm{C}$ to $430^{\circ} \mathrm{C}$ (i.e., temperature of the oven at which maximum of hydrocarbon forms during Rock-Eval pyrolysis) (Kujau et al., 2012; Levert \& Ferry, 1988; Reboulet et al., 2003). This implies that in the marl beds of the Vergol-Morénas section, the thermal diagenesis was not sufficient to trigger illitization of the smectite layers by incorporation of potassium, as this process starts when the organic matter evolves from immature to mature (Deconinck \& Debrabant, 1985; Dellisanti et al., 2010; Levert \& Ferry, 1988). The presence of I-S R1 may be an indicator of such an evolution. In the eastern part of the Vocontian Basin, where the level of thermal diagenesis was higher, the content in I-S R1 decreases from the lower to the upper Valanginian strata (Duchamp-Alphonse et al., 2011). In the Vergol-Morénas section, this trend is opposite and seems to be related to higher detritism. Thus, illitization of smectite in marls appears limited, and we interpret the presence of I-S R1 to be related to weathering of 

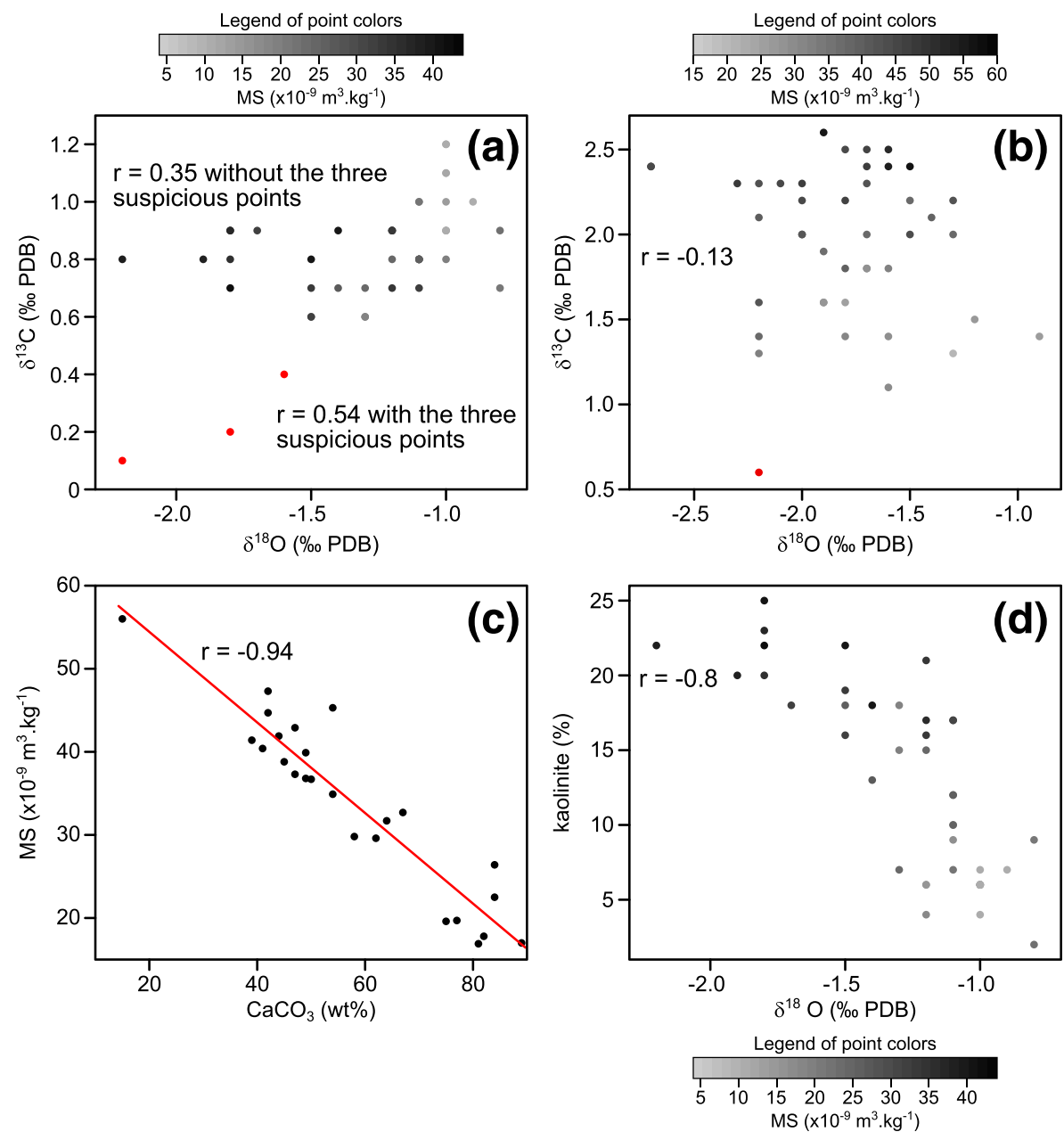

Figure 6. (a) Crossplots of the $\delta^{18} \mathrm{O}_{\text {carb }}$ and the $\delta^{13} \mathrm{C}_{\text {carb }}$ series in Sequence 1 (S1). The correlation coefficients are calculated for the whole of S1 and after removing three suspicious data (in red). (b) In S2 with in red a suspicious point. (c) Crossplot of the MS values and the wt $\% \mathrm{CaCO}_{3}$ content. (d) Crossplot of the kaolinite content within the clay mineral assemblages and the $\delta^{18} \mathrm{O}_{\text {carb }}$ values in S1. The color points reflect the MS values, related to the content in detrital particles.

material containing I-S R1 or to the moderate weathering of illite. Limestone beds in S1 have higher chlorite contents than in their adjacent marl beds (Figures 4 and 5). In limestone beds, the dissolution of high-magnesium calcite releases $\mathrm{Mg}$, which can be incorporated into smectite layers to form chlorite (Deconinck \& Debrabant, 1985). Thus, the short-term cycles observed in the chlorite content can be attributed to postdepositional processes. Despite this decrease in the amount of smectite in limestone beds, our data show that the content of smectite is still higher in limestone beds than in marls, reflecting primary fluctuations of smectite contents.

The fluctuations of kaolinite, smectite, and illite contents thus reflect changes of environmental conditions. Increases in kaolinite and illite contents in marls, and in smectite content in limestone beds, have been observed throughout the Western Tethys areas in the Lower Saxony Basin (Mutterlose \& Ruffell, 1999), in the Subbetic Domain (Moiroud et al., 2012), and in other sections in the Vocontian Basin (Cotillon et al., 1980; Deconinck \& Debrabant, 1985). The clay mineral assemblages also correlate with the nannofossil fluxes, which increase in the marl beds (Giraud et al., 2013; Gréselle et al., 2011; Mattioli et al., 2014; Reboulet et al., 2003). The clay mineral assemblages represent cyclic changes of the levels of weathering in continents. The deposition of marl beds occurred during low seasonality and humid conditions, which led to higher levels of hydrolysis and weathering on continents and to increased detrital and nutrient export to the basin. In turn, these climatic conditions led to increased trophic levels and pelagic productivity 
paceceanograph

Table 1

Proportion of Detrital Particles and Pelagic and Nonpelagic Carbonates In or Near the Sequences Studied

\begin{tabular}{|c|c|c|c|c|c|c|c|c|}
\hline Sequence & & $\begin{array}{c}\text { Proportion } \\
\text { detritism (\%) }\end{array}$ & $\begin{array}{c}\text { Proportion } \\
\text { pelagic } \\
\text { carbonates }(\%)\end{array}$ & $\begin{array}{c}\text { Proportion } \\
\text { nonpelagic } \\
\text { carbonates (\%) }\end{array}$ & $\begin{array}{c}\text { Proportion } \\
\text { pelagic } \\
\text { carbonate } \\
\text { within bulk } \\
\text { carbonate }(\%)\end{array}$ & $\begin{array}{l}\text { Accumulation } \\
\text { rate detritism } \\
\left(\mathrm{cm} \mathrm{kyr}^{-1}\right)\end{array}$ & $\begin{array}{c}\text { Accumulation } \\
\text { rate } \\
\text { pelagic } \\
\text { carbonates } \\
\left(\mathrm{cm} \mathrm{kyr}^{-1}\right)\end{array}$ & $\begin{array}{c}\text { Accumulation rate } \\
\text { nonpelagic } \\
\text { carbonates } \\
\left(\mathrm{cm} \mathrm{kyr}^{-1}\right)\end{array}$ \\
\hline \multirow{3}{*}{$\begin{array}{l}\text { Beds } \\
\quad 75 \mathrm{c}-82 \text {-limestone }\end{array}$} & Average & 20 & 5 & 75 & 6 & 0.9 & 0.2 & 3.2 \\
\hline & Minimum & 12 & 0 & 58 & 0 & 0.3 & 0 & 1.8 \\
\hline & Maximum & 33 & 12 & 86 & 17 & 1.5 & 0.5 & 4.8 \\
\hline \multirow[t]{3}{*}{ Beds $75 \mathrm{c}-82-$ marl } & Average & 45 & 8 & 47 & 15 & 2.4 & 0.4 & 2.5 \\
\hline & Minimum & 32 & 0 & 41 & 0 & 1.8 & 0 & 1.8 \\
\hline & Maximum & 54 & 20 & 54 & 29 & 3.0 & 1.1 & 3.2 \\
\hline \multirow[t]{3}{*}{$\mathrm{S} 2$} & Average & 49 & 19 & 32 & 38 & 3.1 & 1.2 & 2.0 \\
\hline & Minimum & 23 & 11 & 10 & 20 & 1.5 & 0.7 & 0.6 \\
\hline & Maximum & 60 & 35 & 53 & 78 & 3.8 & 2.2 & 3.4 \\
\hline
\end{tabular}

Note. Data are from Gréselle et al. (2011); accumulation rates are calculated from the sedimentation rates provided in Martinez et al. (2013).

(Mattioli et al., 2014; Duchamp-Alphonse et al., 2014; Figure 1c). The detrital proxies and the clay mineral assemblages in S1 thus show an obvious record of the precession and the 405-kyr eccentricity cycle, while in S2, they show an obvious cycle trend, which follows the 405-kyr eccentricity cycle (Figure 4). Detrital and weathering proxies are in phase before and during the Weissert event.

\subsection{Relations Between Lithology and Carbon Isotope Ratios}

\subsubsection{Source of Carbonates in the Early Cretaceous in the Vocontian Basin}

In $\mathrm{S} 2$, the $\delta^{13} \mathrm{C}_{\text {carb }}$ values increase from level 105 to $117 \mathrm{~m}$ and slightly decrease toward the top of S2 (Figure 4). This trend covaries with the MS, kaolinite, and illite series, while the smectite series shows an opposite trend (Figure 4). In S1, the $\delta^{13} \mathrm{C}_{\text {carb }}$ curve shows a trend to stable values throughout the sequence. In detail, the $\delta^{13} \mathrm{C}_{\text {carb }}$ values are systematically higher in limestone beds than in their adjacent marl beds from level of 60 to $65 \mathrm{~m}$ (average values: 1.1\%o PDB in limestone beds; 0.6\% PDB in marl beds) (Figures 4 and 5). Above and below this interval, the $\delta^{13} \mathrm{C}_{\text {carb }}$ values do not display significant differences between marl and limestone beds (average values: 0.8\% PDB in both marl and limestone beds).

The source of carbonate in the marl and the limestone beds of the Vergol-Morénas section was explored in Reboulet et al. (2003), Gréselle et al. (2011), and Mattioli et al. (2014). At Vergol-Morénas, the flux of pelagic carbonates (i.e., from pelagic producers) versus nonpelagic carbonates was quantified from Bed 76 upward, that is, it starts above S1 and encompasses S2. The flux of pelagic carbonates remains low until Bed 82 and rapidly increases upward (Gréselle et al., 2011). The interval from Beds 76 to 82 is thus regarded as the best equivalent to $\mathrm{S} 1$ in terms of pelagic versus nonpelagic carbonate fluxes.

In $\mathrm{S} 2$, the $\mathrm{CaCO}_{3}$ content ranges from $15 \%$ to $67 \%$, with an average value of $47 \%$. In this interval, the nannofossil flux is the highest in the Vergol-Morénas section (Gréselle et al., 2011; Mattioli et al., 2014) probably due to higher trophic conditions following increased detrital and nutrient input to the basin (Bornemann \& Mutterlose, 2008; Mattioli et al., 2014; Figure 1c). In S2, the pelagic carbonate accounts on average for $40 \%$ of the total carbonate and reaches up to $80 \%$ (Gréselle et al., 2011; Table 1). The mean sedimentation rate in this interval is $6.4 \mathrm{~cm} \mathrm{kyr}^{-1}$ (Martinez et al., 2013), implying a mean accumulation rate of the pelagic carbonate of $1.2 \mathrm{~cm} \mathrm{kyr}^{-1}$, a mean accumulation of the nonpelagic carbonate of $2.0 \mathrm{~cm} \mathrm{kyr}^{-1}$, and a mean accumulation rate of the detrital fraction of $3.1 \mathrm{~cm} \mathrm{kyr}^{-1}$ (Table 1).

In $\mathrm{S} 1$, the $\mathrm{CaCO}_{3}$ content ranges from $41 \%$ to $89 \%$, with an average value of $65 \%$ (average in marl beds: $50 \%$; average in limestone beds: 82\%). Quantification of pelagic versus nonpelagic carbonate fluxes from Beds 76 to 82 shows that in limestone beds, the pelagic carbonate accounts on average for $6 \%$ of the total carbonate, with a maximum of $17 \%$ (Table 1). In marl beds, it accounts on average for $15 \%$ of the total carbonate, with a maximum of $30 \%$. The marl-limestone alternations correspond to the record of the precession cycle in this interval (e.g., Gréselle \& Pittet, 2010; Martinez et al., 2013). Assuming a mean duration of 20.3 kyr of the precession cycle (Waltham, 2015) in which a bed represents a half a precession cycle, the mean accumulation 
rate of pelagic carbonate in limestone beds is $0.2 \mathrm{~cm} \mathrm{kyr}^{-1}$ with a maximum value of $0.5 \mathrm{~cm} \mathrm{kyr}^{-1}$ (Table 1). The mean accumulation rate of nonpelagic carbonates is $3.2 \mathrm{~cm} \mathrm{kyr}^{-1}$, and the mean accumulation rate of the detrital fraction is $0.9 \mathrm{~cm} \mathrm{kyr}^{-1}$. In marl beds, the mean accumulation rate of pelagic carbonate is $0.4 \mathrm{~cm} \mathrm{kyr}^{-1}$, with a maximum of $1.1 \mathrm{~cm} \mathrm{kyr}^{-1}$. The mean accumulation rate of the nonpelagic carbonate is $2.5 \mathrm{~cm} \mathrm{kyr}^{-1}$, and the mean accumulation rate of the detrital fraction is $2.4 \mathrm{~cm} \mathrm{kyr}^{-1}$. The flux of carbonate from the pelagic producers shows a broad correlation with the detrital flux in S1 and S2, reflecting higher levels of productivity in the basin following increased detrital and nutrient supply in a humid climate.

The flux of nonpelagic carbonate increased during the deposition of limestone beds under more arid climate and composed the majority of the carbonate fraction in the Vocontian Basin. The marl-limestone alternations follow the clay mineral assemblages. In addition, microfauna and macrofauna do not show selective preservation related to the $\mathrm{CaCO}_{3}$ content. The ammonite abundance does not follow the lithology, while bivalves and gastropods are more abundant in marl than limestone beds (Mattioli et al., 2014; Reboulet et al., 2003). These observations do not agree with a model of diagenetic redistribution of $\mathrm{CaCO}_{3}$ during shallow diagenesis (Cherns \& Wright, 2009; Munnecke et al., 2001). The amount of carbonate in the basin mirrors the carbonate productivity in the surrounding platforms and margins (Reboulet et al., 2003; Gréselle et al., 2011; Figure 1). In the margins of the Vocontian Basin, carbonates notably contain tempestites showing decreased grain size toward the basin (Gréselle \& Pittet, 2010; Virgone \& Masse, 1997). This suggests that the nonpelagic carbonates were exported from the platforms through resuspension during storm events and redeposition basinward of carbonate mud (Reboulet et al., 2003). The types of carbonate producers changed from aragonitic photozoan to calcitic heterozoan producers during the T. pertransiens Zone in the Jura and Helvetic platforms, probably following increased humid climatic conditions, nutrient input, and trophic levels (Morales et al., 2013, 2016). The $\delta^{13} \mathrm{C}_{\text {carb }}$ values in the Jura and Helvetic platforms follow the trends observed in the Vocontian Basin, and their average values around the minimum in the $\delta^{13} \mathrm{C}_{\text {carb }}$ curve range from $0.1 \%$ o to $1.1 \%$, lower or in line with the values in the Vocontian Basin (Morales et al., 2013, 2016). Meanwhile, photozoan producers still existed in the Provence Platform (Bonin et al., 2012; Morales et al., 2016; Virgone, 1997). $\delta^{13} \mathrm{C}_{\text {carb }}$ data are scarcer than in the Jura and Helvetic platforms. They seem to show values in line of the values observed in the Vocontian Basin (Bonin et al., 2012) or 0.5\%o to 1\%o heavier than in the basin (Hennig-Fischer, 2003). The highest $\delta^{13} \mathrm{C}_{\text {carb }}$ values are observed at 3\%o PDB in the internal platform environments (Hennig-Fischer, 2003).

\subsubsection{Contribution of Postdepositional Processes on the Carbon Isotope Ratios}

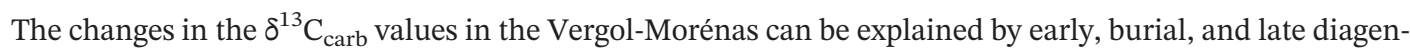
esis, the initial mineralogy of the carbonate, the ecology of the carbonate producers, the dissolved inorganic carbon value and size, and the ratio between organic and inorganic carbon stored on a global scale. In S2, no

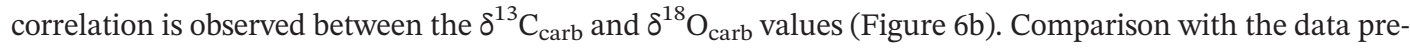
viously published in the Vergol-Morénas section indicates that a value at level $105 \mathrm{~m}$ is significantly lower than its adjacent values and is regarded as suspicious (Figures 3 and 4). In $\mathrm{S} 1$, the $\delta^{13} \mathrm{C}_{\text {carb }}$ and $\delta^{18} \mathrm{O}_{\text {carb }}$ values show a moderate correlation $(r=0.54)$, which appears to be in part supported by lithology (Figure 6a). Three samples show particularly low values in marl beds (Figures 3 and 6a). In these samples, late diagenesis or oxidation of organic matter may have decreased both the carbon and oxygen isotope ratios. The correlation coefficient between the $\delta^{13} \mathrm{C}_{\text {carb }}$ and $\delta^{18} \mathrm{O}_{\text {carb }}$ values is much lower after excluding these three samples $\left(r=0.35\right.$; Figure $6 \mathrm{a}$ ). Importantly, the $\delta^{13} \mathrm{C}_{\text {carb }}$ values observed in the Vergol-Morénas are the same as in the same interval of other sections in the basin having experienced various levels of burial diagenesis (Charbonnier et al., 2013; Duchamp-Alphonse et al., 2007; Gréselle et al., 2011; Hennig et al., 1999;

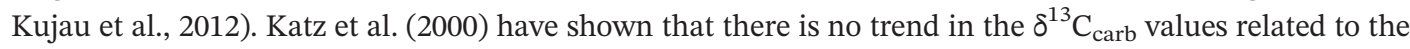
level of the burial diagenesis. Comparatively, the $\delta^{18} \mathrm{O}_{\text {carb }}$ values of the same time intervals become depleted eastward, which reflects increased thermal diagenesis during alpine deformation (see also van de Schootbrugge et al., 2000).

Shallow burial diagenesis could provoke short-term cycles in the carbon and oxygen isotope ratios by dissolving aragonite in clay-richer intervals and precipitation of low-magnesium calcite in carbonate-rich intervals (Cherns \& Wright, 2009; Munnecke et al., 2001; Westphal, 2006). According to this model, the difference in $\mathrm{CaCO}_{3}$ content between marl and limestone beds in the precursor sediment should be subtle, that is, less than $10 \%$. This phenomenon tends to increase the carbon and oxygen isotope ratios in marl beds and 


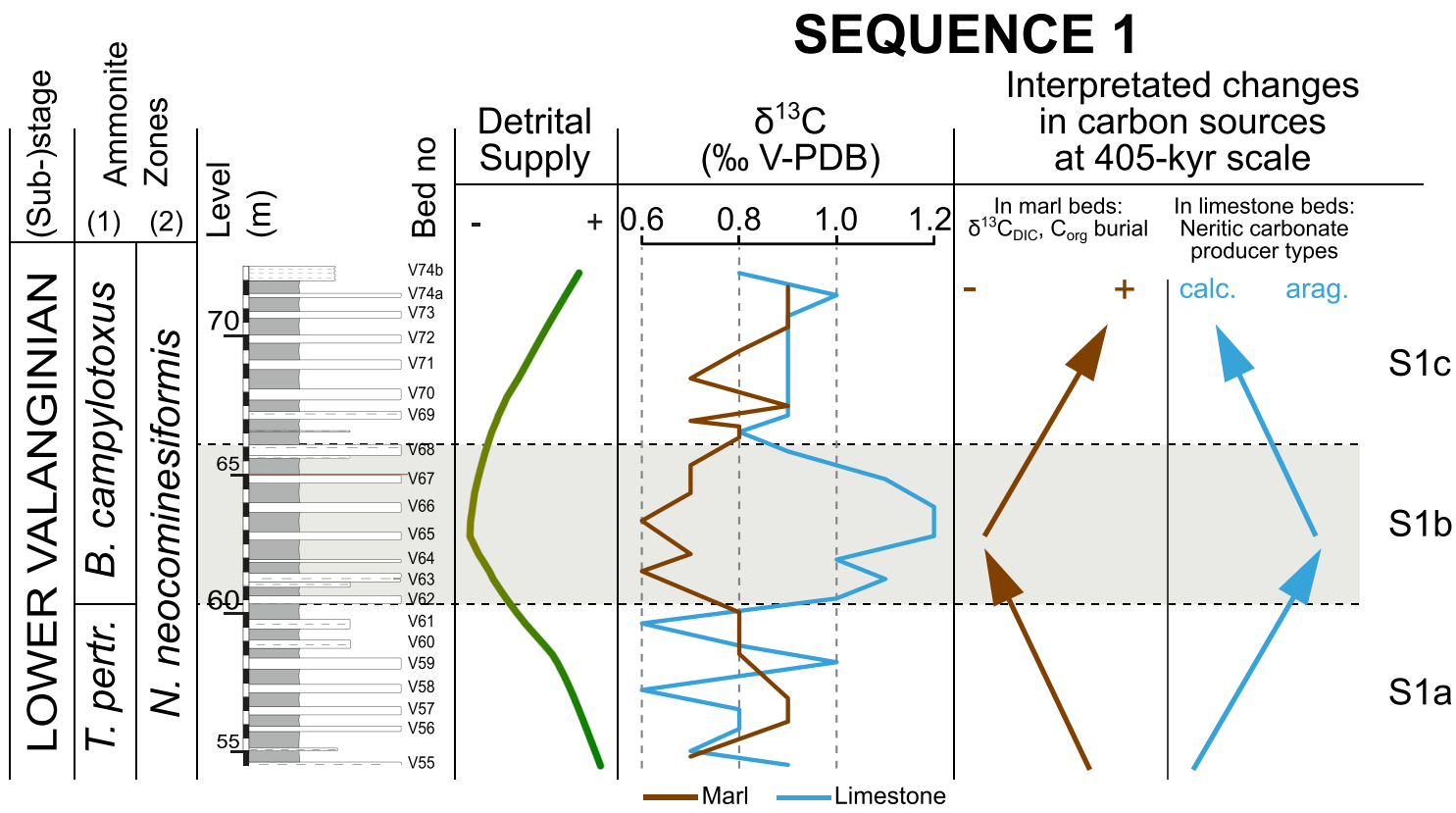

Figure 7. Comparison of the trend of the magnetic susceptibility with the $\delta^{13} \mathrm{C}_{\text {carb }}$ series in marl and limestone beds in S1. (1) Biostratigraphic scheme following Reboulet et al. (2011). (2) Biostratigraphic scheme following Reboulet et al. (2014).

decrease these ratios in limestone beds (Frank et al., 1999; Thierstein \& Roth, 1991). Analyses of the shape of burrows in the Hauterivian strata in other sections of the basin, which experienced similar burial conditions (Gaillard \& Jautée, 1987), suggest that compaction started with early dewatering of sediments and continued during the deep burial phase. No stylolite is observed in the limestone beds. As stated above, the quality of preservation of the faunal assemblages is not related to the $\mathrm{CaCO}_{3}$ content, and the abundances of nannofossils, bivalves, and gastropods are even higher in marl beds (Gréselle et al., 2011; Mattioli et al., 2014; Reboulet et al., 2003). The microfauna and macrofauna observations thus do not follow the pattern of early dissolution of carbonate in carbonate-depleted intervals and reprecipitation in carbonate-rich intervals. The difference in $\mathrm{CaCO}_{3}$ content between marl and limestone beds $(31 \%$ on average) is mostly primary as it follows the clay mineral assemblages.

In $\mathrm{S} 1$, the $\delta^{18} \mathrm{O}_{\text {carb }}$ values are higher in limestone beds than in marls, which is the opposite predicted if the cycles were controlled by dissolution-reprecipitation during the shallow burial diagenesis. Similar carbon isotope values observed at a given time interval throughout the Vocontian Basin suggest at least basin-scale control on these values (Föllmi et al., 2006; Martinez et al., 2015). The trends in the $\delta^{18} \mathrm{O}_{\text {carb }}$ values are also identical throughout the basin, despite the fact that values are shifted to negative values eastward. This suggests that the $\delta^{18} \mathrm{O}_{\text {carb }}$ values are affected by precipitation during the thermal diagenesis. The trends however reflect fluctuations in the mean $\delta^{18} \mathrm{O}_{\text {carb }}$ value of the carbonate deposited in the basin. It is noteworthy that in $\mathrm{S} 1$, the $\delta^{18} \mathrm{O}_{\text {carb }}$ values decrease with increasing kaolinite contents, leading to a strong inverse correlation ( $r=-0.8$; Figure $6 \mathrm{~d}$ ). These changes can reflect warmer and/or more humid conditions during the deposit of marl beds, with increased freshwater and meteoric input to the basin. These data suggest that the trends of the $\delta^{13} \mathrm{C}_{\mathrm{carb}}$ and $\delta^{18} \mathrm{O}_{\text {carb }}$ curves reflect the fluctuations of the carbon and oxygen isotope ratios of the carbonate deposited in the basin. Postdepositional processes nonetheless decreased the $\delta^{13} \mathrm{C}_{\text {carb }}$ values of 4 points, which are not discussed any further.

\subsubsection{Impact of Environmental Processes on the Trends in the Carbon Isotope Ratios}

In marl beds of $\mathrm{S} 1$ and $\mathrm{S} 2$, the $\delta^{13} \mathrm{C}_{\mathrm{carb}}$ values correlate with the detrital flux, the kaolinite, and the illite contents (Figures 4, 5, and 7). In both $\mathrm{S} 1$ and $\mathrm{S} 2$, the trends in the $\delta^{13} \mathrm{C}_{\text {carb }}$ series follow the 405 -kyr eccentricity cycles observed in the MS signal and clay mineral assemblages. Thus, in marl beds, the $\delta^{13} \mathrm{C}_{\text {carb }}$ values increase with the weathering level, detrital flux, and the pelagic production during low seasonality humid climatic conditions. These environmental conditions favored a low level of carbonate production from the shallow-marine environments in which heterozoan calcitic producers were 
dominant. As the pelagic producers were also mainly calcitic, the carbon isotope signatures are comparable from the platform to the basin (Morales et al., 2016; Mutti et al., 2006). Thus, the trends in the $\delta^{13} \mathrm{C}_{\mathrm{carb}}$ series in marl beds in S1 and S2 reflect regional or global climate changes and may, for instance, be related to the balance between organic and inorganic carbon burial in continental and marine domains (e.g., Lini et al., 1992; Bornemann \& Mutterlose, 2008; Westermann et al., 2010; Mattioli et al., 2014; Charbonnier et al., 2020; Figure 1c).

The trend of $\delta^{13} \mathrm{C}_{\text {carb }}$ values in limestone beds of $\mathrm{S} 1$ still follows a 405-kyr eccentricity cycle (Figure 7). However, the trend is in the opposite direction of the trend of $\delta^{13} \mathrm{C}_{\text {carb }}$ values in marl beds and increases during the most arid time in S1. Pelagic producers reach their lowest fluxes during arid times because of a decrease in trophic levels. This environmental setting could however have favored the production of carbonate in the photozoan platforms (Mutti \& Hallock, 2003; Halfar et al., 2004; Figure 1a) still persistent in Provence (Virgone, 1997). Photozoan platforms usually show higher $\delta^{13} \mathrm{C}_{\text {carb }}$ values than heterozoan because the aragonite fractionates to heavier carbon and because photosynthesis from benthic algae locally increases the seawater $\delta^{13} \mathrm{C}$ value (Flügel, 2004; Porter, 2010; Romanek et al., 1992). On average, the carbonate exported from shallow-marine, photozoan, environment tends to increase the $\delta^{13} \mathrm{C}_{\text {carb }}$ values of periplatform sediments (Godet et al., 2006; Swart, 2008; Swart \& Eberli, 2005; Turpin et al., 2012).

Interestingly, the tempestites observed in the Provence Platform commonly exhibit a bundling pattern, which is attributed to the 100- and 405-kyr eccentricity cycles (Gréselle \& Pittet, 2010; Virgone \& Masse, 1997), suggesting a link between environmental conditions and amount of carbonate exported from the Provence Platform. At the beginning and the end of S1 (respectively S1a and S1c), no significant difference exists in the $\delta^{13} \mathrm{C}_{\text {carb }}$ values between marl and limestone beds. This can be due to the fact that the export of calcite from heterozoan platforms was favored during increasingly humid intervals (Figure 1b) or to a homogenization of the carbon isotopes ratios between marl and limestone beds. As the intervals of homogenous values between marl and limestone beds follow the climatic variables, the first scenario appears to be the most likely. During the most arid times, the increase in export of aragonite from photozoan platforms increased the $\delta^{13} \mathrm{C}_{\mathrm{carb}}$ value by $0.6 \%$ PDB. Assuming that the $\delta^{13} \mathrm{C}_{\mathrm{DIC}}$ value corresponded to the lowest values observed in Interval S1b (i.e., $0.6 \%$ PDB) and that calcitic producers precipitated at equilibrium with DIC and a $\delta^{13} \mathrm{C}$ value of 3\% PDB of the aragonitic producers in the Provence Platform, about $25 \%$ of the carbonate of the limestone could come from the export of aragonite. Assuming a maximum value of 5\% PDB, as observed in modern Great Bahama Bank (Swart \& Eberli, 2005), the contribution of the aragonitic export to the total $\mathrm{CaCO}_{3}$ content would be reduced to less than $15 \%$.

\subsection{Implications for Astrochronology}

The presented $\delta^{13} \mathrm{C}_{\mathrm{carb}}$ series shows two distinct responses to the orbital forcing, depending on the main source of carbonate (Figures 7 and 8). In marl beds of both $\mathrm{S} 1$ and $\mathrm{S} 2$, the $\delta^{13} \mathrm{C}_{\text {carb }}$ values increase with increasing humidity, reflecting increased trophic conditions, pelagic primary productivity, and organic carbon storage cycles. Thus, if measured in marl beds only, the $\delta^{13} \mathrm{C}_{\text {carb }}$ series seems to provide a faithful record of the 405-kyr eccentricity cycles. Eccentricity cycles usually have extremely low amplitudes in the spectra of the insolation series, as the energy of the eccentricity is contained in the amplitude of the precession cycles. Erosion and pedogenesis are diffusive processes that can disrupt the amplitude modulation of the precession cycles and permit the direct expression of the eccentricity cycles in the spectra of the paleoclimatic series (Martinez, 2018). As primary productivity partly depends on the nutrient input favored by increased continental weathering, they depend on the diffusive processes and are thus prone to record directly the eccentricity cycles (e.g. Beaufort et al., 1997).

In limestone beds of $\mathrm{S} 1$, the $\delta^{13} \mathrm{C}_{\mathrm{carb}}$ signal reflects the change in the type of carbonate producers, from photozoan to heterozoan, between S1a-S1c and S1b. It thus increases in more arid periods and decreases in more humid periods, which is the exact opposite trend, as observed in marl beds (Figure 7). Whereas the $\delta^{13} \mathrm{C}_{\text {carb }}$ values in marls reflect Tethyan-scale or global-scale change in climate, the trend in the $\delta^{13} \mathrm{C}_{\text {carb }}$ values in limestone beds reflects local, basin-scale changes in the type of carbonate exported to the basin from the surrounding carbonate platforms. The $\delta^{13} \mathrm{C}_{\text {carb }}$ signal in limestone beds seems to be able to record the 405-kyr eccentricity cycle (Figure 7), probably as a consequence of changes in detrital input and trophic levels. Nonetheless, spectral analyses performed on a $\delta^{13} \mathrm{C}_{\text {carb }}$ series measured on samples collected 


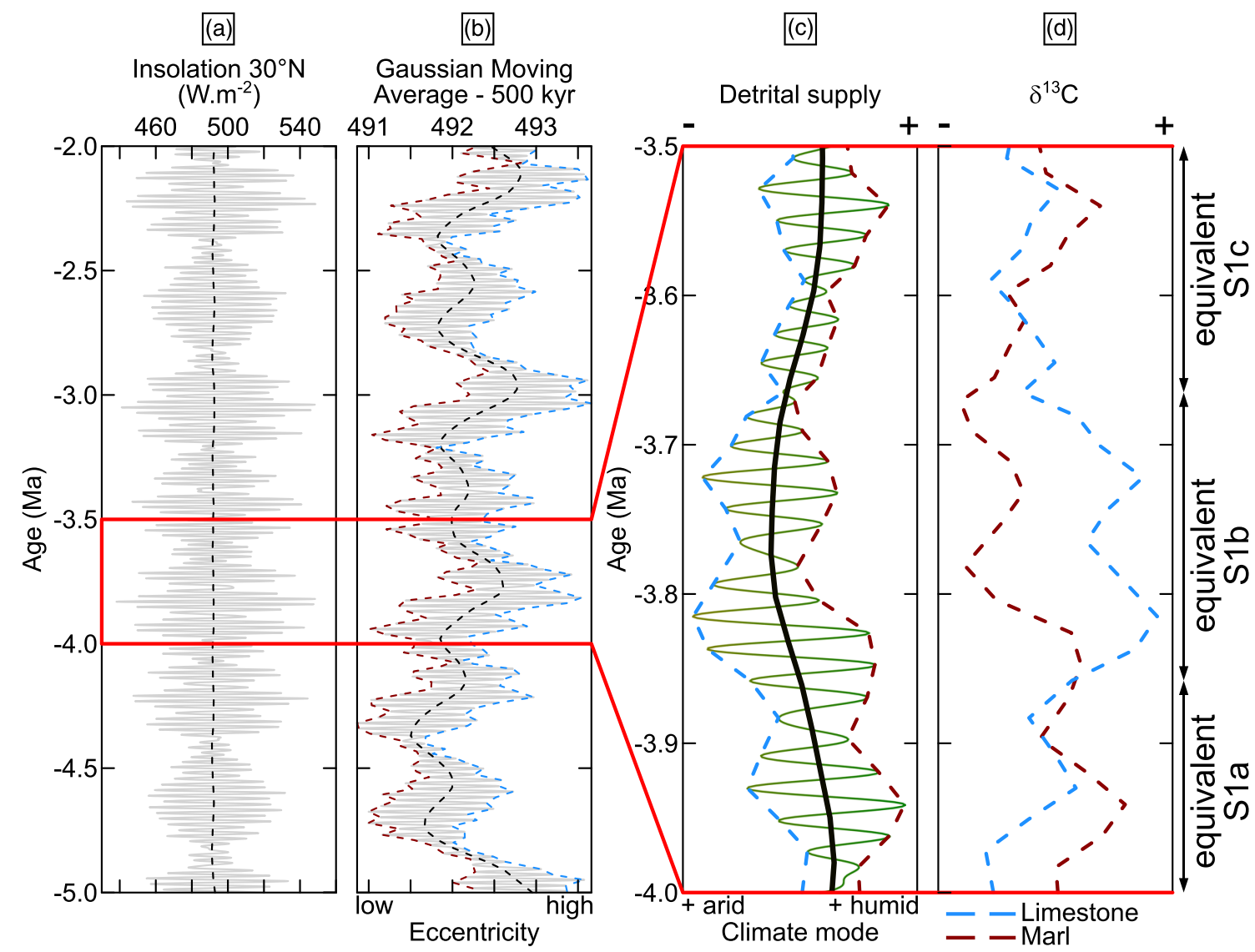

Figure 8. Distortion of the insolation series to the climatic proxies. (a) Insolation series from 2 to 5 Ma (in gray) with a LOWESS smoothing curve (black dotted curve) calculated over $5 \%$ of the series length. The red curve corresponds to the function of the Gaussian function used to calculate the weighted moving average (see panel b.). The interval was selected arbitrarily to cover one complete 2.4-Myr eccentricity cycle within the last 40 Myr, where the astronomical solutions show negligible uncertainties (Laskar et al., 2004, 2011). (b) Gaussian-weighted moving average (in gray) of the insolation solution shown in panel (a) with, in black, a LOWESS smoothing calculated over 5\% of the series length. In brown, the envelope of the minima, and in blue, the envelope of the maxima. (c) Link between insolation series and detrital supply focused on one 405-kyr eccentricity cycle. Assuming that increased detrital supply occurs during eccentricity minima (see text), the signal shown in this panel is simply the opposite of the signal shown in panel (b). (d) Output $\delta^{13} \mathrm{C}$ values in marl and limestone beds to an input insolation forcing. In marl beds, the $\delta^{13} \mathrm{C}$ series follows the detrital input. In limestone beds, the $\delta^{13} \mathrm{C}$ signal shows an opposite trend to the detrital input.

at an even spacing on these marl-limestone alternations would hardly show the eccentricity cycles, because the opposite trends observed in marl and limestone beds would interfere and disrupt the eccentricity cycles.

Interval S1 highlights how local environmental changes can disrupt the record of the orbital cycles in a sedimentary series. This interval is located at the transition between the T. pertransiens and the B. campylotoxus ammonite zones, now in the $N$. neocomiensiformis Zone, according to the more recent revision of the Tethyan ammonite zonation (Reboulet et al., 2011, 2014). This interval corresponds to the transition between photozoan to heterozoan platforms, which occurred in a long-term trend toward a humid climate (Morales et al., 2013, 2016). Interestingly, during the B. campylotoxus Zone, the Provence Platform still records photozoan ecosystems, while the Jura and Helvetic Platform have already turned into a heterozoan mode (Morales et al., 2016). Within this long-term trend, higher-frequency climate changes may thus have favored the development of heterozoan or photozoan platforms. In turn, it impacted the $\delta^{13} \mathrm{C}$ values of the carbonates exported to the Vocontian Basin by changing the ecological conditions and fractionation of the carbonate produced. Interval S1 seems to be a transitional time between a Berriasian-early Valanginian mode, where higher values in $\delta^{13} \mathrm{C}$ are observed in limestone beds, to a late Valanginian mode, where higher $\delta^{13} \mathrm{C}$ values are observed in marls. Several cases document this change of correlation between carbon isotopes and lithology (Ait-Itto et al., 2018; Bajnai et al., 2017; Laurin et al., 2017; Martinez, 2018). The 
impact of changing the source of carbonate to the basin implies changing the response of the carbon isotopes to the orbital cycles. Consequences are distortions of the eccentricity cycles, modifications in their apparent number of repetitions (cycle counting is then used to calculate durations), and occurrences of "nodes" in the evolutive spectral analyses, that is, bifurcation of the main cycle usually attributed to hiatuses (Meyers \& Sageman, 2004) or to amplitude modulations.

To illustrate this, we distort in Figure 8 an insolation model calculated at $30^{\circ} \mathrm{N}$, the approximate paleolatitude of the Vocontian Basin during the Early Cretaceous (Dercourt et al., 1993). The insolation series was taken in the recent past, where the insolation series are the most accurate (Laskar et al., 2004, 2011). It covers a complete 2.4-Myr eccentricity cycle (Figure 8a). Sedimentary processes such as weathering and pedogenesis have long memory effects (Lin, 2011), which can buffer the short cycles (Armitage et al., 2013). We modeled this buffering effect by applying a Gaussian-weighted moving average oriented to the past (Martinez, 2018; Figure 8b). This disrupts the amplitude modulation of the precession cycles and allows a direct observation of the eccentricity cycles, as in the MS and clay mineral assemblages. We set here a maximum of detrital supply to minima of eccentricity (Figure 8c), as the main events of increased trophic conditions and detrital supply seemed to occur during or near this orbital configuration during the Jurassic and the Cretaceous (Batenburg et al., 2016; Kuhnt et al., 2017; Martinez \& Dera, 2015; Mitchell et al., 2008). Figure $8 \mathrm{c}$ thus shows decreased detrital supply during maxima in eccentricity values. In $\mathrm{S} 1$, the $\delta^{13} \mathrm{C}$ values correlate with detrital flux in marl and show an inverse correlation with detrital flux in limestone beds (Figure 7). To illustrate this, we inverted the trend in the $\delta^{13} \mathrm{C}$ values at the time of decreased detrital supply compared to the trend of the $\delta^{13} \mathrm{C}$ values during times of increased detrital supply (Figure 8d).

The amplitude of the short-term cycles in the $\delta^{13} \mathrm{C}_{\text {carb }}$ signal increases from S1a to S1b and decreases to S1c (Figure 7). In the distortion pattern shown in Figure 8, the configuration of increased amplitude of the $\delta^{13} \mathrm{C}_{\text {carb }}$ signal (Interval S1b) would most likely occur during the time of high eccentricity, while S1a and S1c would be the most likely associated to low eccentricity conditions (Figure 8d). As the response of the carbonate system depends on nutrient and detrital input from the continent, the output $\delta^{13} \mathrm{C}$ signal in both marl and limestone is not linear to the Earth's orbital parameters and the amplitude modulation pattern was already disrupted before the deposit of sediment in the basin. Decreased eccentricity may have favored low seasonality, humid conditions around the Tethyan area in the Jurassic and the Early Cretaceous, thus favoring heterozoan producers and increased primary productivity (Martinez \& Dera, 2015). Conversely, increasing eccentricity may have favored decreased detrital and nutrient input to the basin, favoring photozoan producers and decreasing the amount of organic carbon stored in both continental and oceanic domains, thus increasing the amplitude of the change in $\delta^{13} \mathrm{C}_{\text {carb }}$ signal from a marl to a limestone bed. It thus seems that carbonate-dominated and marl-dominated intervals link to long-term changes in the orbital configuration, potentially allowing the reconstruction of the eccentricity cycles during the Early Cretaceous.

\section{Conclusions}

In the hemipelagic marl-limestone alternations of the Vocontian Basin, marl and limestone beds show two distinct and opposite responses to the orbital forcing, depending on the climatic conditions and the type of carbonate producer on adjacent platforms. The $\delta^{13} \mathrm{C}_{\mathrm{carb}}$ values in marl beds show a positive correlation with the level of detrital input to the basin, reflecting humid/arid cycles and the level of organic carbon stored in

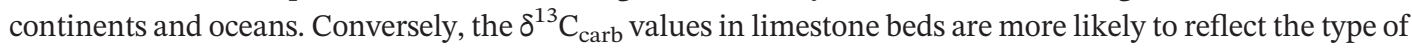
shallow-marine carbonate (photozoan or heterozoan) exported to the basin. Depending on the main type of shallow-marine carbonate producers, the $\delta^{13} \mathrm{C}_{\text {carb }}$ values can be alternatively the highest during the most arid or the most humid times of a 405-kyr eccentricity cycle. These distinct responses disrupted the record of the eccentricity cycles in the carbon isotopes while it is still preserved in clay mineral assemblages and lithological proxies. We show here that coupling the $\delta^{13} \mathrm{C}_{\text {carb }}$ signal with other proxies is essential to test the source of carbonates and the reliability of the carbon isotopes as a proxy for orbital tuning in a marginal basin close to carbonate platforms. From comparisons with insolation series, carbonate-dominated intervals in the Vocontian Basin seem to have occurred during high eccentricity conditions, while more marl-dominated intervals (including the Weissert event) seem to have occurred during low eccentricity conditions. 


\section{Acknowledgments}

M. M. is supported by project "Astronomical Calibration of the Jurassic-Cretaceous boundary" from TelluS Program of CNRS/INSU. All data are stored at Pangaea Data Repository and can be accessed via the following link (https://doi.pangaea.de/ 10.1594/PANGAEA.909741). M. M. designed the study, supervised the MS measurements, interpreted the data, and wrote the manuscript. L. G. measured the bulk MS, clay mineral assemblages, and stable isotope data and contributed in the data interpretations. P. B. supervised the stable isotope measurements and contributed in the data interpretations. J.-F. D. supervised the semiquantification of the clay mineral assemblages, measured the $\mathrm{CaCO}_{3}$ content, and contributed in the data interpretations. We would like to thank warmly Adrian Immenhauser, Baptiste Suchéras-Marx, and associate editor Oliver Friedrich for their helpful, informative, and constructive comments. We acknowledge Morag Johnston for English proofreading.

\section{References}

Ait-Itto, F.-Z., Martinez, M., Price, G. D., \& Addi, A. A. (2020). Synchronization of the astronomical time scales in the Early Toarcian: A link between anoxia, carbon-cycle perturbation, mass extinction and volcanism. Earth and Planetary Science Letters, 493, 1-11. https://doi. org/10.1016/j.epsl.2018.04.007

Armitage, J. J., Jones, T. D., Duller, R. A., Whittaker, A. C., \& Allen, P. A. (2013). Temporal buffering of climate-driven sediment flux cycles by transient catchment response. Earth and Planetary Science Letters, 369, 200-210. https://doi.org/10.1016/j. epsl.2013.03.020

Bajnai, D., Pálfy, J., Martinez, M., Price, G. D., Nyerges, A., \& Főzy, I. (2017). Multi-proxy record of orbital-scale changes in climate and sedimentation during the Weissert Event in the Valanginian Bersek Marl Formation (Gerecse Mts., Hungary). Cretaceous Research, 75, 45-60. https://doi.org/10.1016/j.cretres.2017.02.021

Batenburg, S. J., De Vleeschouwer, D., Sprovieri, M., Hilgen, F. J., Gale, A. S., Singer, B. S., et al. (2016). Orbital control on the timing of oceanic anoxia in the Late Cretaceous. Climate of the Past, 12(10), 1995-2009. https://doi.org/10.5194/cp-12-1995-2016

Beaufort, L., Lancelot, Y., Camberlin, P., Cayre, O., Vincent, E., Bassinot, F., \& Labeyrie, L. (1997). Insolation cycles as a major control of equatorial Indian Ocean primary production. Science, 278(5342), 1451-1454. https://doi.org/10.1126/science.278.5342.1451

Beltran, C., De Rafélis, M., Person, A., Stalport, F., \& Renard, M. (2009). Multiproxy approach for determination of nature and origin of carbonate micro-particles so-called "micarb" in pelagic sediments. Sedimentary Geology, 213, 64-76. https://doi.org/10.1016/j. sedgeo.2008.11.004

Blanc, E. (1996). Transect plate-forme-bassin dans les séries carbonatées du Berriasien supérieur et du Valanginien inférieur (domaines jurassien et nord-vocontien): chronostratigraphie-transferts des sédiments (Doctoral dissertation). Retrieved from TEL-Thèses en Ligne (https://tel.archives-ouvertes.fr/tel-00723723). Grenoble, France: University Joseph Fourier, Grenoble.

Bonin, A., Vennin, E., Pucéat, E., Guiraud, M., Arnaud-Vanneau, A., Adatte, T., et al. (2012). Community replacement of neritic carbonate organisms during the late Valanginian platform demise: A new record from the Provence Platform. Palaeogeography, Palaeoclimatology, Palaeoecology, 365, 57-80. https://doi.org/10.1016/j.palaeo.2012.09.014

Bornemann, A., \& Mutterlose, J. (2008). Calcareous nannofossil and $\delta^{13} \mathrm{C}$ records from the Early Cretaceous of the Western Atlantic Ocean: Evidence for enhanced fertilization across the Berriasian-Valanginian transition. Palaios, 23(12), 821-832. https://doi.org/10.2110/ palo.2007.p07-076r

Charbonnier, G., Boulila, S., Gardin, S., Duchamp-Alphonse, S., Adatte, T., Spangenberg, J. E., et al. (2013). Astronomical calibration of the Valanginian "Weissert" episode: The Orpierre marl-limestone succession (Vocontian Basin, southeastern France). Cretaceous Research, 45, 25-42. https://doi.org/10.1016/j.cretres.2013.07.003

Charbonnier, G., Duchamp-Alphonse, S., Deconinck, J.-F., Adatte, T., Spangenberg, J. E., Colin, C., \& Föllmi, K. B. (2020). A global palaeoclimatic reconstruction for the Valanginian based on clay mineralogical and geochemical data. Earth-Science Reviews, 202, 103092. https://doi.org/10.1016/j.earscirev.2020.103092

Cherns, L., \& Wright, V. P. (2009). Quantifying the impacts of early diagenetic aragonite dissolution on the fossil record. Palaios, 24(11), 756-771. https://doi.org/10.2110/palo.2008.p08-134r

Cleveland, W. S. (1979). Robust locally weighted regression and smoothing scatterplots. Journal of the American Statistical Association, 74(368), 829-836. https://doi.org/10.1080/01621459.1979.10481038

Colombié, C., \& Strasser, A. (2003). Depositional sequences in the Kimmeridgian of the Vocontian Basin (France) controlled by carbonate export from shallow-water platforms. Geobios, 36(6), 675-683. https://doi.org/10.1016/j.geobios.2003.03.004

Cotillon, P., Ferry, S., Gaillard, C., Jautée, E., Latreille, G., \& Rio, M. (1980). Fluctuation des paramètres du milieu marin dans le domaine vocontien (France Sud-Est) au Crétacé inférieur: mise en évidence par l'étude des formations marno-calcaires alternantes. Bulletin de la Société géologique de France, 7(22), 735-744. https://doi.org/10.2113/gssgfbull.S7-XXII.5.735

Cotillon, P. (1987). Bed-scale cyclicity of pelagic Cretaceous successions as a result of world-wide control. Marine Geology, 78(1-2), 109-123. https://doi.org/10.1016/0025-3227(87)90070-3

Deconinck, J.-F. (1987). Identification de l'origine détritique ou diagénétique des assemblages argileux: le cas des alternances marne-calcaire du Crétacé inférieur subalpin. Bulletin de la Société Géologique de France, 3(1), 139-145. https://doi.org/10.2113/ gssgfbull.III.1.139

Deconinck, J.-F., \& Chamley, H. (1983). Héritage et diagenèse des minéraux argileux dans les alternances marno-calcaires du Crétacé inférieur du domaine subalpin. Comptes-rendus des séances de l'Académie des sciences. Série 2, Mécanique-physique, chimie, sciences de l'univers, sciences de la terre, 297(7), 589-594.

Deconinck, J.-F., \& Debrabant, P. (1985). Diagénèse des argiles dans le domaine subalpin: rôles respectifs de la lithologie, de l'enfouissement et de la surcharge tectonique. Revue de géologie dynamique et de géographie physique, 26(5), 321-330.

Dellisanti, F., Pini, G. A., \& Baudin, F. (2010). Use of $T_{\max }$ as a thermal maturity indicator in orogenic successions and comparison with clay mineral evolution. Clay Minerals, 45(1), 115-130. https://doi.org/10.1180/claymin.2010.045.1.115

Dercourt, J., Ricou, L. E., \& Vrielynck, B. (1993). Atlas Tethys palaeoenvironmental maps. Paris, France: Gauthier-Villars.

Duchamp-Alphonse, S., Fiet, N., Adatte, T., \& Pagel, M. (2011). Climate and sea-level variations along the northwestern Tethyan margin during the Valanginian C-isotope excursion: Mineralogical evidence from the Vocontian Basin (SE France). Palaeogeography, Palaeoclimatology, Palaeoecology, 302, 243-254. https://doi.org/10.1016/j.palaeo.2011.01.015

Duchamp-Alphonse, S., Gardin, S., \& Bartolini, A. (2014). Calcareous nannofossil response to the Weissert episode (Early Cretaceous): Implications for palaeoecological and palaeoceanographic reconstructions. Marine Micropaleontology, 113, 65-78. https://doi.org/ 10.1016/j.marmicro.2014.10.002

Duchamp-Alphonse, S., Gardin, S., Fiet, N., Bartolini, A., Blamart, D., \& Pagel, M. (2007). Fertilization of the northwestern Tethys (Vocontian basin, SE France) during the Valanginian carbon isotope perturbation: Evidence from calcareous nannofossils and trace element data. Palaeogeography, Palaeoclimatology, Palaeoecology, 243, 132-151. https://doi.org/10.1016/j.palaeo.2006.07.010

Einsele, G., \& Ricken, W. (1991). Limestone-marl alternation-An overview. In G. Einsele, W. Ricken, \& A. Seilacher (Eds.), Cycles and events in stratigraphy, (pp. 23-47). Heidelberg, Germany: Springer-Verlag.

Erba, E., Bartolini, A., \& Larson, L. R. (2004). Valanginian Weissert oceanic anoxic event. Geology, 32(2), 149-152. https://doi.org/10.1130/ G20008.1

Flügel, E. (2004). Microfacies of carbonate rocks. Berlin, Heidelberg, Germany: Springer.

Föllmi, K. B., Godet, A., Bodin, S., \& Linder, P. (2006). Interactions between environmental change and shallow water carbonate buildup along the northern Tethyan margin and their impact on the Early Cretaceous carbon isotope record. Paleoceanography, 21, PA4211. https://doi.org/10.1029/2006PA001313 
Frank, T. D., Arthur, M. A., \& Dean, W. A. (1999). Diagenesis of Lower Cretaceous pelagic carbonates, North Atlantic: Paleoceanographic signal obscured. Journal of Foraminiferal Research, 29(4), 340-351.

Gaillard, C., \& Jautée, E. (1987). The use of burrows to detect compaction and sliding in fine-grained sediments: An example from the Cretaceous of SE France. Sedimentology, 34(4), 585-593. https://doi.org/10.1111/j.1365-3091.1987.tb00788.x

Ghirardi, J., Deconinck, J.-F., Pellenard, P., Martinez, M., Bruneau, L., Amiotte-Suchet, P., \& Pucéat, E. (2014). Multi-proxy orbital chronology in the aftermath of the Aptian Oceanic Anoxic Event 1a: Palaeoceanographic implications (Serre Chaitieu section, Vocontian Basin, SE France). Newsletters on Stratigraphy, 47(3), 247-262. https://doi.org/10.1127/0078-0421/2014/0046

Gilbert, G. K. (1895). Sedimentary measurement of Cretaceous time. The Journal of Geology, 3(2), 121-127. https://doi.org/10.1086/607150

Giorgioni, M., Weissert, H., Bernasconi, S. M., Hochuli, P. A., Coccioni, R., \& Keller, C. E. (2012). Orbital control on carbon cycle and oceanography in the mid-Cretaceous greenhouse. Paleoceanography, 27, PA1204. https://doi.org/10.1029/2011PA002163

Giraud, F., Beaufort, L., \& Cotillon, P. (1995). Periodicities of carbonate cycles in the Valanginian of the Vocontian Trough: A strong obliquity control. Geological Society, London, Special Publications, 85, 143-164. https://doi.org/10.1144/GSL.SP.1995.085.01.09

Giraud, F., Reboulet, S., Deconinck, J.-F., Martinez, M., Carpentier, A., \& Bréziat, C. (2013). The Mid-Cenomanian Event in southeastern France: Evidence from palaeontological and clay mineralogical data. Cretaceous Research, 46, 43-58. https://doi.org/10.1016/j. cretres.2013.09.004

Godet, A., Bodin, S., Föllmi, K. B., Vermeulen, J., Gardin, S., Fiet, N., et al. (2006). Evolution of the marine stable carbon-isotope record during the early Cretaceous: A focus on the late Hauterivian and Barremian in the Tethyan realm. Earth and Planetary Science Letters, 242, 254-271. https://doi.org/10.1016/j.epsl.2005.12.011

Gradstein, F. M., Ogg, J. G., Schmitz, M. D., \& Ogg, G. M. (2012). The geologic time scale 2012. Amsterdam, The Netherlands: Elsevier B.V.

Gréselle, B., \& Pittet, B. (2010). Sea-level reconstructions from the Peri-Vocontian Zone (South-east France) point to Valanginian glacioeustasy. Sedimentology, 57, 1640-1684. https://doi.org/10.1111/j.1365-3091.2010.01159.x

Gréselle, B., Pittet, B., Mattioli, E., Joachimski, M., Barbarin, N., Riquier, L., et al. (2011). The Valanginian isotope event: A complex suite of palaeoenvironmental perturbations. Palaeogeography, Palaeoclimatology, Palaeoecology, 306, 41-57. https://doi.org/10.1016/j. palaeo.2011.03.027

Grippo, A., Fischer, A. G., Hinnov, L. A., Herbert, T. D., \& Premoli Silva, I. (2004), Cyclostratigraphy and chronology of the Albian stage (Piobbico core, Italy). In B. D'Argenio, Fischer, A. G., Premoli Silva, I., Weissert, H., Ferreri, V. (Eds.), Cyclostratigraphy: Approaches and case histories, SEPM Special Publications (Vol. 81, pp. 57-81), Tulsa, OK: SEPM (Society for Sedimentary Geology)

Halfar, J., Godinez-Orta, L., Mutti, M., Valdez-Holguín, J. E., \& Borges, J. M. (2004). Nutrient and temperature controls on modern carbonate production: An example from the Gulf of California, Mexico. Geology, 32(3), 213-216. https://doi.org/10.1130/G20298.1

Hays, J. D., Imbrie, J., \& Shackleton, N. J. (1976). Variations in the Earth's orbit: Pacemaker of the ice ages. Science, 194(4270), 1121-1132. https://doi.org/10.1126/science.194.4270.1121

Hennig, S., Weissert, H., \& Bulot, L. (1999). C-isotope stratigraphy, a calibration tool between ammonite- and magnetostratigraphy: The Valanginian-Hauterivian transition. Geologica Carpathica, 50(1), 91-95.

Hennig-Fischer, S. (2003). Geochemical and sedimentological evidence for environmental changes in the Valanginian (Early Cretaceous) of the Tethys region (Doctoral dissertation). Retrieved from ETH Zürich Research Collection (https://www.research-collection.ethz.ch/ bitstream/handle/20.500.11850/147527/1/eth-26561-01.pdf). Zürich, Switzerland: Eidgenössische Technische Hochschule Zürich (ETHZ).

Herbert, T. D., Stallard, R. F., \& Fischer, A. G. (1986). Anoxic events, productivity rhythms, and the orbital signature in a mid-Cretaceous deep-sea sequence from Central Italy. Paleoceanography, 1(4), 495-506. https://doi.org/10.1029/PA001i004p00495

Hinnov, L. A., \& Hilgen, F. J. (2012). Cyclostratigraphy and astrochronology. In F. M. Gradstein, J. G. Ogg, M. D. Schmitz, \& G. M. Ogg (Eds.), The geologic time scale 2012, (pp. 63-83). Amsterdam, The Netherlands: Elsevier B.V.

Huang, C., Hesselbo, S. P., \& Hinnov, L. (2010). Astrochronology of the late Jurassic Kimmeridge Clay (Dorset, England) and implications for Earth system processes. Earth and Planetary Science Letters, 289(1-2), 242-255. https://doi.org/10.1016/j.epsl.2009.11.013

Jarvis, I., Gale, A. S., Jenkyns, H. C., \& Pearce, M. A. (2006). Secular variation in Late Cretaceous carbon isotopes: A new $\delta^{13} \mathrm{C}$ carbonate reference curve for the Cenomanian-Campanian (99.6-70.6 Ma). Geological Magazine, 143(5), 561-608. https://doi.org/10.1017/ S0016756806002421

Katz, B., Elmore, R. D., Cogoini, M., Engel, M. H., \& Ferry, S. (2000). Associations between burial diagenesis of smectite, chemical remagnetization, and magnetite authigenesis in the Vocontian trough, SE France. Journal of Geophysical Research, 105(B1), 851-868. https://doi.org/10.1029/1999JB900309

Kenjo, S., Mattioli, E., Reboulet, S., Bert, D., \& Ma'Loulleh, K. (2014). Integrated biostratigraphy of calcareous nannofossils and ammonoids. Implications for the definition of the stratotype of the Berriasian-Valanginian boundary (139.4 Ma). In R. Rocha, J. Pais, J. C. Kullberg, \& S. Finney (Eds.), STRATI 2013, (pp. 261-265). Heidelberg, Germany: Springer Geology.

Kuhnt, W., Holbourn, A. E., Beil, S., Aquit, M., Krawczyk, T., Flögel, S., et al. (2017). Unraveling the onset of Cretaceous Oceanic Anoxic Event 2 in an extended sediment archive from the Tarfaya-Laayoune Basin, Morocco. Paleoceanography, 32(8), 923-946. https://doi. org/10.1002/2017pa003146

Kujau, A., Heimhofer, U., Ostertag-Henning, C., Gréselle, B., \& Mutterlose, J. (2012). No evidence for anoxia during the Valanginian carbon isotope event-An organic-geochemical study from the Vocontian Basin, SE France. Global and Planetary Change, 92-93, 92-104. https://doi.org/10.1016/j.gloplacha.2012.04.007

Lamas, F., Irigaray, C., Oteo, C., \& Chacon, J. (2005). Selection of the most appropriate method to determine the carbonate content for engineering purposes with particular regard to marls. Engineering Geology, 81(1), 32-41. https://doi.org/10.1016/j. enggeo.2005.07.005

Laskar, J., Fienga, A., Gastineau, M., \& Manche, H. (2011). La2010: A new orbital solution for the long-term motion of the Earth. Astronomy and Astrophysics, 532, A89. https://doi.org/10.1051/0004-6361/201116836

Laskar, J., Robutel, P., Joutel, F., Gastineau, M., Correia, A. C. M., \& Levrard, B. (2004). A long-term numerical solution for the insolation quantities of the Earth. Astronomy and Astrophysics, 428, 261-285. https://doi.org/10.1051/0004-6361:20041335

Laurin, J., Růžek, B., \& Giorgioni, M. (2017). Orbital signals in carbon isotopes: Phase distortion as a signature of the carbon cycle. Paleoceanography, 32, 1236-1255. https://doi.org/10.1002/2017PA003143

Levert, J., \& Ferry, S. (1988). A complex clay diagenesis in the Mesozoic French Subalpine Basin as revealed by mapping of clay assemblages along isochronous levels. Bulletin de la Société Géologique de France, 4(6), 1029-1038. https://doi.org/10.2113/gssgfbull.IV.6.1029

Li, M., Huang, C., Ogg, J., Zhang, Y., Hinnov, L., Wu, H., et al. (2019). Paleoclimate proxies for cyclostratigraphy: Comparative analysis using a Lower Triassic marine section in South China. Earth-Science Reviews, 189, 125-146. https://doi.org/10.1016/j. earscirev.2019.01.011 
Lin, H. (2011). Three principles of soil change and pedogenesis in time and space. Soil Science Society of America Journal, 75(6), 2049-2070. https://doi.org/10.2136/sssaj2011.0130

Lini, A., Weissert, H., \& Erba, E. (1992). The Valanginian carbon isotope event: A first episode of greenhouse climate conditions during the Cretaceous. Terra Nova, 4(3), 374-384. https://doi.org/10.1111/j.1365-3121.1992.tb00826.x

Martinez, M. (2018). Mechanisms of preservation of the eccentricity and longer-term Milankovitch cycles in detrital supply and carbonate production in hemipelagic marl-limestone alternations. In M. Montenari (Ed.), Cyclostratigraphy and astrochronology, stratigraphy and timescales, (Vol. 3, pp. 189-218). London, United Kingdom: Elsevier Inc. https://doi.org/10.1016/bs.sats.2018.08.002

Martinez, M., Deconinck, J.-F., Pellenard, P., Reboulet, S., \& Riquier, L. (2013). Astrochronology of the Valanginian Stage from reference sections (Vocontian Basin, France) and palaeoenvironmental implications for the Weissert Event. Palaeogeography, Palaeoclimatology, Palaeoecology, 376, 91-102. https://doi.org/10.1016/j.palaeo.2013.02.021

Martinez, M., Deconinck, J.-F., Pellenard, P., Riquier, L., Company, M., Reboulet, S., \& Moiroud, M. (2015). Astrochronology of the Valanginian-Hauterivian stages (Early Cretaceous): Chronological relationships between the Paraná-Etendeka large igneous province and the Weissert and the Faraoni events. Global and Planetary Change, 131, 158-173. https://doi.org/10.1016/j.gloplacha.2015.06.001

Martinez, M., \& Dera, G. (2015). Orbital pacing of carbon fluxes by a 9-My eccentricity cycle during the Mesozoic. Proceedings of the National Academy of Sciences of the United States of America, 112(41), 12604-12609. https://doi.org/10.1073/pnas.1419946112

Mattioli, E., Pittet, B., Riquier, L., \& Grossi, V. (2014). The mid-Valanginian Weissert Event as recorded by calcareous nannoplankton in the Vocontian Basin. Palaeogeography, Palaeoclimatology, Palaeoecology, 414, 472-485. https://doi.org/10.1016/j.palaeo.2014.09.030

Matys Grygar, T., Hošek, M., Mach, K., Schnabl, P., \& Martinez, M. (2017). Climatic instability before the Miocene Climatic Optimum reflected in a Central European lacustrine record from the Most Basin in the Czech Republic. Palaeogeography, Palaeoclimatology, Palaeoecology, 485, 930-945. https://doi.org/10.1016/j.palaeo.2017.08.011

McArthur, J. M., Janssen, N. M. M., Reboulet, S., Leng, M. J., Thirlwall, M. F., \& van de Schootbrugge, B. (2007). Palaeotemperatures, polar ice-volume, and isotope stratigraphy $\left(\mathrm{Mg} / \mathrm{Ca}, \delta^{18} \mathrm{O}, \delta^{13} \mathrm{C},{ }^{87} \mathrm{Sr} /{ }^{86} \mathrm{Sr}\right)$ : The Early Cretaceous (Berriasian, Valanginian, Hauterivian). Palaeogeography, Palaeoclimatology, Palaeoecology, 248, 391-430. https://doi.org/10.1016/j.palaeo.2006.12.015

Meyers, S. R., \& Sageman, B. B. (2004). Detection, quantification, and significance of hiatuses in pelagic and hemipelagic strata. Earth and Planetary Science Letters, 224, 55-72. https://doi.org/10.1016/j.epsl.2004.05.003

Mitchell, R. N., Bice, D. M., Montanari, A., Cleaveland, L. C., Christianson, K. T., Coccioni, R., \& Hinnov, L. A. (2008). Oceanic anoxic cycles? Orbital prelude to the Bonarelli Level (OAE 2). Earth and Planetary Science Letters, 267(1-2), 1-16. https://doi.org/10.1016/j. epsl.2007.11.026

Moiroud, M., Martinez, M., Deconinck, J.-F., Monna, F., Pellenard, P., Riquier, L., \& Company, M. (2012). High-resolution clay mineralogy as a proxy for orbital tuning: Example of the Hauterivian-Barremian transition in the Betic Cordillera (SE Spain). Sedimentary Geology, 282, 336-346. https://doi.org/10.1016/j.sedgeo.2012.10.004

Moore, D. M., \& Reynolds, R. C. (1997). X-ray diffraction and the identification and analysis of clay minerals. Oxford, United Kingdom: Oxford University Press.

Morales, C., Gardin, S., Schnyder, J., Spangenberg, J., Arnaud-Vanneau, A., Arnaud, H., et al. (2013). Berriasian and early Valanginian environmental change along a transect from the Jura Platform to the Vocontian Basin. Sedimentology, 60, 36-63. https://doi.org/ $10.1111 /$ sed.12019

Morales, C., Spangenberg, J. E., Arnaud-Vanneau, A., Adatte, T., \& Föllmi, K. B. (2016). Evolution of the northern Tethyan Helvetic Platform during the late Berriasian and early Valanginian. The Depositional Record, 2(1), 47-73. https://doi.org/10.1002/dep2.13

Munnecke, A., Westphal, H., Elrick, M., \& Reijmer, J. (2001). The mineralogical composition of precursor sediments of calcareous rhythmites: A new approach. International Journal of Earth Sciences, 90(4), 795-812. https://doi.org/10.1007/s005310000137

Mutterlose, J., \& Ruffell, A. (1999). Milankovitch-scale palaeoclimate changes in pale-dark bedding rhythms from the Early Cretaceous (Hauterivian and Barremian) of eastern England and northern Germany. Palaeogeography, Palaeoclimatology, Palaeoecology, 154, 133-160. https://doi.org/10.1016/S0031-0182(99)00107-8

Mutti, M., \& Hallock, P. (2003). Carbonate systems along nutrient and temperature gradients: Some sedimentological and geochemical constraints. International Journal of Earth Sciences, 92(4), 465-475. https://doi.org/10.1007/s00531-003-0350-y

Mutti, M., John, C. M., \& Knoerich, A. C. (2006). Chemostratigraphy in Miocene heterozoan carbonate settings: Applications, limitations and perspectives. Geological Society, London, Special Publications, 255(1), 307-322. https://doi.org/10.1144/GSL.SP.2006.255.01.18

Pälike, H., Frazier, J., \& Zachos, J. C. (2006). Extended orbitally forced palaeoclimatic records from the equatorial Atlantic Ceara Rise. Quaternary Science Reviews, 25, 3138-3149. https://doi.org/10.1016/j.quascirev.2006.02.011

Petschick, R. (2000). MacDiff 4.2.5. Retrieved from: http://servermac.geologie.uni-frankfurt.de/Rainer.html

Pittet, B., \& Mattioli, E. (2002). The carbonate signal and calcareous nannofossil distribution in an Upper Jurassic section (BalingenTieringen, Late Oxfordian, southern Germany). Palaeogeography, Palaeoclimatology, Palaeoecology, 179, 71-96. https://doi.org/10.1016/ S0031-0182(01)00409-6

Pittet, B., \& Strasser, A. (1998). Depositional sequences in deep-shelf environments formed through carbonate-mud import from the shallow platform (Late Oxfordian, German Swabian Alb and eastern Swiss Jura). Eclogae Geologicae Helvetiae, 91, 149-169. https://doi. org/10.5169/seals- 168414

Porter, S. M. (2010). Calcite and aragonite seas and the de novo acquisition of carbonate skeletons. Geobiology, 8, 256-277. https://doi.org/ 10.1111/j.1472-4669.2010.00246.x

Reboulet, S. (1996). L'évolution des ammonites du Valanginien-Hauterivien inférieur du bassin vocontien et de la plate-forme provençale (SE de la France): relations avec la stratigraphie séquentielle et implications biostratigraphiques (Doctoral dissertation). Lyon, France: University Claude Bernard, Lyon 1.

Reboulet, S., \& Atrops, F. (1999). Comments and proposals about the Valanginian-Lower Hauterivian ammonite zonation of south-eastern France. Eclogae Geologicae Helvetiae, 92, 183-197. https://doi.org/10.5169/seals-168660

Reboulet, S., Mattioli, E., Pittet, B., Baudin, F., Olivero, D., \& Proux, O. (2003). Ammonoid and nannoplankton abundance in Valanginian (early Cretaceous) limestone-marl successions from the southeast France Basin: Carbonate dilution or productivity? Palaeogeography, Palaeoclimatology, Palaeoecology, 201, 113-139. https://doi.org/10.1016/S0031-0182(03)00541-8

Reboulet, S., Rawson, P. F., Moreno-Bedmar, J. A., Aguirre-Urreta, M. B., Barragán, R., Bogomolov, Y., et al. (2011). Report on the 4th International Meeting of the IUGS Lower Cretaceous Ammonite Working Group, the "Kilian Group" (Dijon, France, 30th August 2010). Cretaceous Research, 32, 786-793. https://doi.org/10.1016/j.cretres.2011.05.007

Reboulet, S., Szives, O., Aguirre-Urreta, B., Barragán, R., Company, M., Idakieva, V., et al. (2014). Report on the 5th International Meeting of the IUGS Lower Cretaceous Ammonite Working Group, the Kilian Group (Ankara, Turkey, 31st August 2013). Cretaceous Research, 50, 126-137. https://doi.org/10.1016/j.cretres.2014.04.001 
Rodríguez-Tovar, F. J., Löwemark, L., \& Pardo-Igúzquiza, E. (2011). Zoophycos cyclicity during the last 425 ka in the northeastern South China Sea: Evidence for monsoon fluctuation at the Milankovitch scale. Palaeogeography, Palaeoclimatology, Palaeoecology, 305, 256-263. https://doi.org/10.1016/j.palaeo.2011.03.006

Romanek, C. S., Grossman, E. L., \& Morse, J. W. (1992). Carbon isotopic fractionation in synthetic aragonite and calcite: Effects of temperature and precipitation rate. Geochimica et Cosmochimica Acta, 56(1), 419-430. https://doi.org/10.1016/0016-7037(92)90142-6

Strasser, A., Hilgen, F. J., \& Heckel, P. H. (2006). Cyclostratigraphy-Concepts, definitions, and applications. Newsletters on Stratigraphy, 42(2), 75-114. https://doi.org/10.1127/0078-0421/2006/0042-0075

Suchéras-Marx, B., Mattioli, E., Pittet, B., Escarguel, G., \& Suan, G. (2010). Astronomically-paced coccolith size variations during the early Pliensbachian (Early Jurassic). Palaeogeography, Palaeoclimatology, Palaeoecology, 295, 281-292. https://doi.org/10.1016/j. palaeo.2010.06.006

Swart, P. K. (2008). Global synchronous changes in the carbon isotopic composition of carbonate sediments unrelated to changes in the global carbon cycle. Proceedings of the National Academy of Sciences, 105(37), 13741-13745. https://doi.org/10.1073/pnas.0802841105

Swart, P. K., \& Eberli, G. (2005). The nature of the $\delta^{13} \mathrm{C}$ of periplatform sediments: Implications for stratigraphy and the global carbon cycle. Sedimentary Geology, 175, 115-129. https://doi.org/10.1016/j.sedgeo.2004.12.029

Thierstein, H. R., \& Roth, P. H. (1991). Stable isotopic and carbonate cyclicity in Lower Cretaceous deep-sea sediments: Dominance of diagenetic effects. Marine Geology, 97(1-2), 1-34. https://doi.org/10.1016/0025-3227(91)90017-X

Turpin, M., Emmanuel, L., Immenhauser, A., \& Renard, M. (2012). Geochemical and petrographical characterization of fine-grained carbonate particles along proximal to distal transects. Sedimentary Geology, 281, 1-20. https://doi.org/10.1016/j.sedgeo.2012.06.008

Vahlenkamp, M., De Vleeschouwer, D., Batenburg, S. J., Edgar, K. M., Hanson, E., Martinez, M., et al. (2020). A lower to middle Eocene astrochronology for the Mentelle Basin (Australia) and its implications for the geologic time scale. Earth and Planetary Science Letters, 529, 115865. https://doi.org/10.1016/j.epsl.2019.115865

van de Schootbrugge, B., Föllmi, K. B., Bulot, L. G., \& Burns, S. J. (2000). Paleoceanographic changes during the early Cretaceous (Valanginian-Hauterivian): Evidence from oxygen and carbon stable isotopes. Earth and Planetary Science Letters, 181, 15-31. https:// doi.org/10.1016/S0012-821X(00)00194-1

Van Os, B. J. H., Lourens, L. J., Hilgen, F., De Lange, G. J., \& Beaufort, L. (1994). The formation of Pliocene sapropels and carbonate cycles in the Mediterranean: Diagenesis, dilution, and productivity. Paleoceanography, 9, 601-617. https://doi.org/10.1029/94PA00597

Virgone, A. (1997). Stratigraphie, sédimentologie et dynamique d'une plate-forme carbonatée: le Berriasien supérieur-Valanginien basal de Basse Provence occidentale (SE. France) (Doctoral dissertation). Marseille,France: University Aix-Marseille.

Virgone, A., \& Masse, J. P. (1997). Les dépôts carbonates de tempêtes du « Faisceau bioclastique du Mont-Rose » (Valanginien inférieurMarseille, Sud-Est de la France). Geologie Alpine, 72, 127-143. http://geologie-alpine.ujf-grenoble.fr/fitem?id=GA_1996_72_127_0

Waltham, D. (2015). Milankovitch period uncertainties and their impact on cyclostratigraphy. Journal of Sedimentary Research, 85(8), 990-998. https://doi.org/10.2110/jsr.2015.66

Weissert, H., Lini, A., Föllmi, K. B., \& Kuhn, O. (1998). Correlation of Early Cretaceous carbon isotope stratigraphy and platform drowning events: A possible link? Palaeogeography, Palaeoclimatology, Palaeoecology, 137, 189-203. https://doi.org/10.1016/S00310182(97)00109-0

Westermann, S., Föllmi, K. B., Adatte, T., Matera, V., Schnyder, J., Fleitmann, D., et al. (2010). The Valanginian $\delta^{13}$ C excursion may not be an expression of a global oceanic anoxic event. Earth and Planetary Science Letters, 290(1-2), 118-131. https://doi.org/10.1016/j. epsl.2009.12.011

Westphal, H. (2006). Limestone-marl alternations as environmental archives and the role of early diagenesis: A critical review. International Journal of Earth Sciences, 95(6), 947-961. https://doi.org/10.1007/s00531-006-0084-8

Wilpshaar, M., \& Leereveld, H. (1994). Palaeoenvironmental change in the Early Cretaceous Vocontian Basin (SE France) reflected by dinoflagellate cysts. Review of Palaeohotany and Palynology, 84, 121-128. https://doi.org/10.1016/0034-6667(94)90046-9

Zachos, J. C., Shackleton, N. J., Revenaugh, J. S., Pälike, H., \& Flower, B. P. (2001). Climate response to orbital forcing across the Oligocene-Miocene boundary. Science, 292, 274-278. https://doi.org/10.1126/science.1058288

Zeeden, C., Kaboth, S., Hilgen, F. J., \& Laskar, J. (2018). Taner filter settings and automatic correlation optimisation for cyclostratigraphic studies. Computers and Geosciences, 119, 18-28. https://doi.org/10.1016/j.cageo.2018.06.005 